\title{
Finite element vibration and dynamic response analysis of engineering structures
}

\author{
A bibliography (1994-1998)
}

\author{
Jaroslav Mackerle \\ Linköping Institute of Technology, Department of \\ Mechanical Engineering, S-581 83 Linköping, Sweden
}

Received 14 September 1999

Revised 8 November 1999

This bibliography lists references to papers, conference proceedings, and theses/dissertations dealing with finite element vibration and dynamic response analysis of engineering structures that were published from 1994 to 1998. It contains 539 citations. The following types of structures are included: basic structural systems; ground structures; ocean and coastal structures; mobile structures; and containment structures.

\section{Introduction}

Information is the most valuable, but least valued, tool the professional has. The output of scientific papers keeps growing, making it more difficult to be upto-date with all the relevant information. The number of channels that researchers and practicing engineers have at their disposal for information retrieval is also increasing. In engineering, informal knowledge channels are the most frequently used means of obtaining information. Many professionals prefer to rely on personal judgment or on the wisdom of their colleagues whenever they have problems to solve. Hopefully, this bibliography will save time for readers.

Advanced numerical methods, for which finite element methods are the most efficient and most frequently used, are extremely important for complicated engineering structures such as spacecraft, airplanes, automobiles, buildings, bridges, dams, containment vessels, etc. By means of dynamic analyses and simulations one can determine whether a structure under consideration will fulfill its function, and the results of the dynamic loadings acting on this structure can be predicted. In this way, it can be determined which structural parameter most affects the dynamic response. Then, the structure can be modified and functionally improved. Both time response and frequency response calculations of a system may be performed. Additionally, nonlinear effects often have to be considered in the design/analysis of structures to improve their performances and to increase the operating range. Nonlinear finite element analysis can improve the design of such structures. It should be noted that the area of dynamic response analysis where the finite element method is implemented still requires significant research and development in two main directions: the development of more effective basic procedures, and the enhancement of the solution of large systems of equations.

This bibliography provides a list of references on finite element vibration and dynamic response analysis of engineering structures. General solution techniques as well as problem-specific applications are included. The entries have been retrieved from the author's database, MAKEBASE [1,2]. The references have been published in scientific journals, conference proceedings, theses and dissertations between 1994 and 1998. They are sorted in each category alphabetically according to the first author's name. If a specific paper is relevant for several subject categories, the same reference will be listed under all appropriate section headings; interested readers should also consider areas adjacent to their central area of research. Listed references are grouped into the following sections and subsections:

- basic structural systems

- ground structures (trusses/frames/buildings and walls; bridges; dams; piles, foundations and underground structures; pavements; and other structures)

- ocean and coastal structures

- mobile structures (aircraft, helicopters, and aerospace structures; automobiles; ships; railways and trains; and other structures) 
- containment structures (reactors and pressure vessels; pipes; storage tanks and other structures)

Not included in the bibliography are impact problems, crashworthiness, rotor dynamics, dynamic analysis of structural elements, dynamic analysis of machine elements, vibration control and aerodynamic problems.

Readers interested in finite element literature in general are referred to [3] or to the author's Internet Finite Element Books Bibliography (http://www.solid.ikp.liu. se/fe/index.html).

\section{Basic structural systems}

The topics in this section contain papers dealing with: free vibration analysis; computation of eigenfrequencies/natural frequencies; 2D and 3D linear and nonlinear dynamic response analysis; dynamic forced response; structural deterioration by dynamic response; modal analysis of structures with imprecise material properties; structures under cyclic or moving loads; damping characteristics; dynamic testing of structures; NDE of the dynamic response; adaptive methods; and stochastic analysis.

Materials under consideration include: metals; steel; concrete; steel-concrete; composites; laminated composites; reinforced/unreinforced masonry; and brickwork.

In this section the following structures and structural systems are handled: joined beams; plate assemblies; beam-plate assemblies; beam-column structures; loosely jointed structures; flexible systems; long flexible structures; panels; perforated panels; sandwich panels; honeycomb sandwich structures; arches; circular arches; shallow arches; arches with cracks; slabs; girders; lattice girders; post-tensioned girders; beam grillages; thin-walled structures; tubular structures; repetitive structures; lattice structures; tension structures; suspended structures; cable stayed structures; sliding cable systems; and antivibration mounts.

\section{Ground structures}

This section contains the following subsections: trusses/frames/buildings and walls; bridges; dams; piles, foundations and underground structures; pavements; and other structures. Topics included for all these subcategories are: 2D and 3D, linear and nonlinear dynamic response analysis; modal analysis; hybrid inverse eigenmode problems; vibration analysis; forced vibration response; vibration analysis of cracked structures; walking/traffic vibration problems; structures under random traffic excitations; natural frequency evaluation; vibration mode localization; parametric identification; dynamic analysis of structures with uncertainties; reliability analysis; multibody simulations; dynamic experimental testing; influence of damping in dynamic analysis; and parametric studies.

The types of structures discussed are listed for each subcategory separately, as indicated below.

\section{Trusses/frames/buildings and walls}

Trusses; lattice trusses; frames; portal frames; sandwich frames; reinforced concrete infilled frames; buildings; tall buildings; historical buildings; nuclear reactor buildings; reinforced concrete buildings; light frame wood buildings; building floors; shear walls; reinforced concrete shear walls; safety walls; reinforced earth walls; stiffened coupled shear walls; panel precast wall systems; coupled shear wall-frame systems; and structures on elastic foundation.

\section{Bridges}

Bridges; continuous bridges; multi-span/multi-cell bridges; multi-span continuous bridges; long-span bridges; reinforced concrete bridges; prestressed concrete bridges; composite cellular bridges; slender wood bridges; arch bridges; masonry arch bridges; girder bridges; slab-type bridges; through-truss bridges; box girder bridges; curved box girder bridges; cablestayed bridges; long-span cable-stayed bridges; suspension bridges; suspension footbridges; composite footbridges; highway bridges; ship canal bridges; moored floating bridges; bridges with isolation bearings; bridge decks; bridge girder-diaphragm interaction; bridge-vehicle interaction; and repaired bridges.

\section{Dams}

Dams; earth dams; concrete gravity dams; arch dams; high arch dams; inflatable dams; embankment dams; and dam-reservoir- foundation systems.

\section{Piles, foundations and underground structures}

Piles; pile groups; pile foundations; large diameter pile foundations; rigid foundations; deep foundations; raft foundations; footings; tunnels; and subway structures.

\section{Pavements}

Pavements; rigid pavements; flexible pavement systems; concrete pavements; jointed concrete pavements; 
composite pavements; road pavements; airport concrete pavements; pavement discontinuities; and pavements under moving loads.

\section{Other structures}

Guyed towers; elevator towers; reservoir towers; wind turbine towers; articulated towers; lattice towers; church bell towers; cooling towers; thin-walled towers; guyed masts; transmitter masts; transmission lines; thin-walled domes; thermowells; and athletic/sport flooring systems.

\section{Ocean and coastal structures}

This category of structures is not divided into subsections. Topics included here are: 2D and 3D, linear and nonlinear dynamic response analysis; hybrid dynamic analysis; modal analysis; modal parameter estimation; frequency domain analysis; hydrodynamic interactions of waves; mooring dynamics; reliability assessment; and parametric studies.

Types of ocean and coastal structures included in the papers are: floating structures; long floating structures; flexible floating structures; mat-like floating structures; jacket structures; flexible and rigid risers; tension leg platforms; spar platforms; offshore platforms; submarine pipelines; underwater cables; oilfield derrick structures; marine structures; caissons; refinery piers; breakwaters; and pontoon-type breakwaters.

\section{Mobile structures}

The following subsections are included for mobile structures: aircrafts, helicopters and aerospace structures; automobiles; ships; railways and trains; and other structures. Again, as in the Section 3, topics listed are common for all five subsections. They are: 2D and $3 \mathrm{D}$, linear and nonlinear, dynamic response analysis; eigenvalue analysis; modal analysis; vibration analysis; thermally induced vibrations; low frequency vibrations; high frequency vibrations; vibration reduction; wave propagation problems; vehicle-track interaction; and parametric studies.

Types of structures discussed in the papers for each subcategory may include:

\section{Aircraft, helicopters and aerospace structures}

Aircraft and helicopters; wings; supersonic wings; aircraft landing system; aircraft brakes; airframe pan- els; exhaust nozzle; rotor-fuselage problems; elastomeric dampers; fuselage structures; high speed aircraft generators; hydraulic power systems; helicopter rotors; helicopter seats; helicopter skid gears; helicopter tail booms; deployable space structures; deployable satellite antennas; space shuttle main engine; space shuttle tiles; satellite booms; spacecrafts; aerospace structures; asymmetric rockets; and photovoltaic arrays.

\section{Automobiles}

Automobiles; carbodies; body-on-frame automobiles; chassis-suspensions; vehicle suspensions; engines; disc brakes; vehicle drivelines; transmission housing; exhaust pipes; rear-view mirrors; hydraulic engine mounts; vehicle vibration isolation; and energy absorbers.

\section{Ships}

Submersible hulls; double hull structures; sailing monohulls; cargoships; ship deckhouses; ship propulsion systems; and shafts.

\section{Railways and trains}

Railway tracks; lightweight rail track systems; railway passenger car body; synchronous motor driven trains; high-speed trains; and subway structures.

\section{Other structures}

Trucks; truck-trailer vehicles; mining trucks; tracked vehicles; armored vehicles; tractor protective cabs; tractor-trailers; hydraulic cranes; buses; mountain bikes; road bikes; tires; mobile antennas; engines; engine mounts; engine crankshafts; engine blocks; and gearboxes.

\section{Containment structures}

This last part contains the following subjects: reactors and pressure vessels; pipes; storage tanks and other structures. Topics relevant to all three subcategories are: 2D and 3D, linear and nonlinear, dynamic response analysis; vibration studies; flow-induced vibration analysis; vibration analysis in the frequency domain; vibration analysis in the time domain; modal analysis; coupled response analysis; forced vibration analysis; parametric studies. 


\section{Reactors and pressure vessels}

Reactors; CANDU reactors; Tokamak support systems; fuel channels; protective covers; fusion reactor blankets; heat exchangers; steam condensers; thick cylinders; blast containment vessels; and pressure vessels.

\section{Pipes}

Pipes; curved pipes; pressurized elbows; deep ocean pipes; crust mining pipes; nuclear piping; piping systems; pipelines; multi-span pipes; fluid-conveying pipes; cantilever whipping pipes; and compressorpiping systems.

\section{Storage tanks and other structures}

Cylindrical water tanks; rectangular storage tanks; double-decker cylindrical tanks; base isolated liquid storage tanks; clamped-free storage tanks; fluid-filled membrane structures; oil storage tanks; waste storage tanks; and silos.

\section{Acknowledgement}

The bibliography presented is by no means complete but it gives a comprehensive representation of different finite element applications on the subjects covered. The author wishes to apologize for the unintentional exclusions of missing references and would appreciate receiving comments and pointers to other relevant literature for a future update.

\section{References}

[1] J. Mackerle, MAKEBASE, an information retrieval system in structural mechanics for main-frames and personal computers, Eng. Computations 6 (1989), 178-185.

[2] J. Mackerle, An information retrieval system for finite element and boundary element literature and software, Eng. Analysis with Boundary Elements 11 (1993), 177-187.

[3] J. Mackerle, Finite Element Methods, A Guide to Information Sources, Elsevier, Amsterdam, 1991.

\section{BIBLIOGRAPHY}

\section{Basic structural systems}

[1] B.O. Al-Bedoor, Y.A. Khulief, Finite element dynamic modeling of elastic beam with prismatic joint, in: 1995 ASME Design Engineering Technical Conferences DE 82, ASME, 1995, pp. 609-616.
[2] H. Amick et al., Vibration of a room-sized airspringsupported slab, Noise Control Engineering J. 46(2) (1998), 39-47.

[3] Y. Aoki et al., Damping characteristics of weld-bonded box section members, Transactions of the Japan Society of Mechanical Engineers, Ser A 61(590) (1995), 2309-2315.

[4] N.M. Auciello, M.A. De Rosa, Free vibrations of circular arches: a review, J. of Sound and Vibration 176(4) (1994), 433-458.

[5] A. Ayoub, F.C. Filippou, Model for composite steel-concrete girders under cyclic loading, in: 15th Structures Congress, Portland, ASCE, 1997, pp. 721-725.

[6] E. Balmes, Predicted variability and differences between tests of a single structure, in: 16th Int. Modal Analysis Conference, Santa Barbara, 1998, pp. 558-564.

[7] N.S. Bardell et al., Free vibration analysis of thin rectangular laminated plate assemblies using the h-p version of the finite element method, Composite Structures 32(1/4) (1995), 237246.

[8] N.S. Bardell et al., Free vibration analysis of thin coplanar rectangular plate assemblies- Part I: Theory, and initial results for specially orthotropic plates, Composite Structures 34(2) (1996), 129-143.

[9] N.S. Bardell et al., Free vibration analysis of thin coplanar rectangular plate assemblies- Part II: Further results for generally orthotropic plates, Composite Structures 34(2) (1996), 145-162.

[10] G. Barrientos, R. Sampaio, Flexible systems: threedimensional theory in MATLAB, in: 4th World Congress on Computational Mechanics, Buenos Aires, 1998, pp. 274.

[11] G. Bartoli, C. Blasi, Masonry structures, historical buildings and monuments,in: Computer Analysis and Design of Earthquake Resistant Structures, D.E. Beskos, ed, CMP, 1997, pp. 563-606.

[12] A. Bensalem et al., Non-destructive evaluation of the dynamic response of a brickwork arch, Proc. of the Institution of Civil Engineers Structures and Buildings 122(1) (1997), 69-82.

[13] A.N. Bercin, Eigenfrequencies of rectangular plate assemblies, Computers and Structures 65(5) (1997), 703-711.

[14] K.A. Burgemeister, C.H. Hansen, Calculating resonance frequencies of perforated panels, J. of Sound and Vibration 196(4) (1996), 387-399.

[15] W.S. Burton, A.K. Noor, Assessment of continuum models for sandwich panel honeycomb cores, Computer Methods in Applied Mechanics and Engineering 145(3/4) (1997), 341360.

[16] E.G. Callis, The dynamic behavior of nonlinear loosely jointed structures, Ph.D. Thesis, Duke University, 1994.

[17] R. Cerioni et al., Use of incompatible displacement modes in a finite element model to analyze the dynamic behavior of unreinforced masonry panels, Computers and Structures 57(1) (1995), 47-57.

[18] Y.W. Chan et al., Predicting the vibration characteristics of antivibration mounts using the finite element method, JVC/ J. of Vibration and Control 3(1) (1997), 55-76.

[19] A. Chate et al., Free vibration analysis of sandwich plates on flexible supports, Mechanics of Composite Materials and Structures 2(1) (1995), 1-18.

[20] H.L. Chen et al., Evaluating structural deterioration by dynamic response, J. of Structural Engineering, ASCE 121(8) (1995), 1197-1204. 
[21] X. Chen, K.K. Tamma, Dynamic response of elastic thinwalled structures influenced by coupling effects, Computers and Structures 51(1) (1994), 91-105.

[22] L. Cheng, Y.C. Qu, Rotational compliance measurements of a flexible plane structure using an attached beam-like tip, Part 1: Analysis and numerical simulation, J. of Vibration and Acoustics, ASME 119(4) (1997), 596-602.

[23] Y.K. Cheung, J. Kong, Vibration and buckling of thin-walled structures by a new finite strip, Thin-Walled Structures 21(4) (1995), 327-343.

[24] S.A. Choura, A.S. Yigi, Vibration confinement in flexible structures by distributed feedback, Computers and Structures 54(3) (1995), 531-540.

[25] E.M. Daya, M. Potier-Ferry, Vibration and stability modes of long flexible structures, in: 2nd Int. Conference on Computational Structures Technology, Part 1, Athens, 1994, pp. 171177.

[26] H. Deng, L. Vu-Quoc, Dynamics of geometrically exact sandwich structures, Int. J. of Mechanical Sciences 40(5) (1998), 421-441.

[27] S. Finnveden, Spectral finite element analysis of stationary vibrations in a beam-plate structure, Acustica 82(3) (1996), 478-497.

[28] M. Ganapathi et al., Torsional vibration and damping analysis of sandwich beams, J. of Reinforced Plastics and Composites 18(2) (1999), 96-117.

[29] N.F. Grace, B. Ross, Dynamic characteristics of posttensioned girders with web openings, J. of Structural Engineering, ASCE 122(6) (1996), 643-650.

[30] A.K. Gupta, W.P. Howson, Exact natural frequencies of plane structures composed of slender elastic curved members, J. of Sound and Vibration 175(2) (1994), 145-157.

[31] I. Hagiwara, Z.D. Ma, Development of new modesuperposition technique for truncating lower and/or higherfrequency modes, JSME Int. J., Ser C 37(1) (1994), 14-20.

[32] A.S. Hamam, Measuring and modeling dynamic loads imposed by moving crowds, Ph.D. Thesis, The University of Oklahoma, 1994.

[33] A. Hami El Hami, B. Radi, Some decomposition methods in the analysis of repetitive structures, Computers and Structures 58(5) (1996), 973-980.

[34] M. Hayashi, C. Watanabe, Free vibration analysis of thin walled structures by finite node-strip method, Proceedings of Japan Society of Civil Engineers 549(I-37) (1996), 141-148.

[35] A.M. Horr, L.C. Schmidt, A spectrally formulated finite element method for vibration of a tubular structure, Structural Engineering and Mechanics 4(3) (1996), 209-226.

[36] A.M. Horr, L.C. Schmidt, Fractional-spectral method for vibration of damped space structures, Engineering Structures 18(12) (1996), 947-956.

[37] A. Ianakiev, K. Donev, Investigation into dynamic analysis of complex structures using superelements, in: 8th European Simulation Symposium, ESS'96, Ghent, V 2, 1996, pp. $212-$ 216.

[38] T. Ichikawa, I. Hagiwara, Frequency response analysis of large-scale damped structures using component mode synthesis, Transactions of the Japan Society of Mechanical Engineers, Ser C 39(3) (1996), 450-455.

[39] N.P. Jones et al., Effect of stay-cable vibration on buffeting response, in: 15th Structures Congress, Portland, ASCE, 1997, pp. 180-184.

[40] M. Krawczuk, W. Ostachowicz, Natural vibrations of a clamped-clamped arch with an open transverse crack, J. of Vibration and Acoustics, ASME 119(2) (1997), 145-151.
[41] B. Lallemand et al., Fuzzy modal finite element analysis of structures with imprecise material properties, J. of Sound and Vibration 220(2) (1999), 353-364.

[42] R.S. Langley et al., Response of 2D periodic structures to harmonic point loading: a theoretical and experimental study of a beam grillage, J. of Sound and Vibration 207(4) (1997), 521-535.

[43] S. Lenci, A.M. Tarantino, Dynamics of shallow elastic arches, Part II: Optimal forms, European J. of Mechanics, A/Solids 15(3) (1996), 529-543.

[44] R. Leon et al., Cyclic performance of riveted connections, in: Structural Congress XII, Atlanta, ASCE, 1994, pp. 14901495.

[45] E. Levy, M. Eisenberger, Dynamic stiffness analysis of lattice structure, in: 14th Structures Congress, Chicago, ASCE, 1996, pp. 526-533.

[46] W.Y. Li, W.K. Ho, A displacement variational method for free vibration analysis of thin walled members, J. of Sound and Vibration 181(3) (1995), 503-513.

[47] J.L. Lilien, A.P. Da Costa, Vibration amplitudes caused by parametric excitation of cable stayed structures, J. of Sound and Vibration 174 (1) (1994), 69-90.

[48] I.H.P. Mamaghani et al., Inelastic large deflection analysis of structural steel members under cyclic loading, Engineering Structures 18(9) (1996), 659-668.

[49] P. Melnik-Melnikov et al., Nonlinear analysis of thin-walled structures subjected to stationary random loads, in: Structural Safety and Reliability, G.I. Schueller, ed, Balkema, 1994, pp. 173-177.

[50] J.E. Mottershead, G. Lallement, Vibration nodes, and the cancellation of poles and zeros by unit-rank modifications to structures, J. of Sound and Vibration 222(5) (1999), 833-851.

[51] A. Nappi et al., Structural dynamics: convergence properties in the presence of damage and applications to masonry structures, Structural Engineering and Mechanics 5(5) (1997), 587-598.

[52] D.I. Nwosu et al., Dynamic response of tubular T-joints under the influence of propagating cracks, J. of Offshore Mechanics and Arctic Engineering, ASME 118(1) (1996), 71-78.

[53] A. Paolozzi, I. Peroni, A procedure for the determination of effective mass sensitivities in a general tridimensional structure, Computers and Structures 62(6) (1997), 10131024

[54] R.M.O. Pauletti, P.M. Pimenta, Nonlinear dynamic analysis of sliding cable systems, in: 4th World Congress on Computational Mechanics, Buenos Aires, 1998, pp. 291.

[55] R.H. Plaut, A. Hou, Deflections, vibrations, and stability of a pair of leaning arches, J. of Engineering Mechanics, ASCE 124(7) (1998), 748-753.

[56] S.M. Powell et al., Efficient multi-level substructuring with constraints for buckling and vibration analysis of prismatic plate assemblies, Int. J. of Mechanical Sciences 39(7) (1997), 795-805.

[57] Y.C. Qu et al., Rotational compliance measurements of a flexible plane structure using an attached beam-like tip, Part 2: Experimental study, J. of Vibration and Acoustics, ASME 119(4) (1997), 603-608.

[58] S.A. Ramu, R. Ganesan, Response and stability of a stochastic beam-column using stochastic FEM, Computers and Structures 54(2) (1995), 207-221.

[59] J. Ravinger, Vibration of an imperfect thin-walled panel- Part 2: Numerical results and experiment, Thin-Walled Structures 19(1) (1994), 23-36. 
[60] L.V.A. Rebillard, J.L. Guyader, Network vibratory behavior of assembled plates, J. of Physics 4(5) (1994), 121-124.

[61] C.T.F. Ross et al., Vibration of circumferentially corrugated cylinders under uniform external pressure, in: 3rd Joint Conference on Engineering Systems Design and Analysis PD 81, ASME, 1996, pp. 203-207.

[62] R.E. Rossi et al., Dynamic stiffening of orthogonal beam grillages, J. of Sound and Vibration 187(2) (1995), 281-286.

[63] B.T. Rosson et al., Response of lime mortar joint arches to moving loads, in: Worldwide Advances in Structural Concrete and Masonry Proc., Chicago, ASCE, 1996, pp. 223232.

[64] A.B. Sabir, Free vibration steady state response of geometrically nonlinear shallow arches, Thin-Walled Structures 18(2) (1994), 145-159.

[65] A.B. Sabir, Elastic buckling, stability and vibration of linear and geometrically non-linear behavior of structures, in: Energy Sources Technology Conference and Exhibition PD 70, ASME, 1995, pp. 175-181.

[66] A.B. Sabir, M.S. Djoudi, Geometric non-linearity for post buckling and vibration of flat and curved structures, in: $3 r d$ Biennial Joint Conference on Engineering Systems Design and Analysis PD 73, ASME, 1996, pp. 11-21.

[67] A.B. Sabir, A. Sfendji, Natural frequencies of singly and doubly curved panels by the finite element method, in: Energy Sources Technology Conference and Exhibition PD 70, ASME, 1995, pp. 149-157.

[68] A.B. Sabir et al., The effect of shear deformation on the vibration of circular arches by the finite element method, Thin-Walled Structures 18(1) (1994), 47-66.

[69] K. Shankar, A.J. Keane, A study of the vibrational energies of two coupled beams by finite element and Green function (receptance) methods, J. of Sound and Vibration 181(5) (1995), 801-838.

[70] M. Skrinar, A. Umek, Changes in the eigenpairs due to the structure modification: the continuous approach, Engineering Transactions 45(2) (1997), 227-236.

[71] P. Swider et al., Interactions between numerical and experimental approaches in composite structure dynamics, Composite Structures 43(2) (1998), 127-135.

[72] B. Tabarrok, Z. Qin, Dynamic analysis of tension structures, Computers and Structures 62(3) (1997), 467-474.

[73] I. Talvik, Some aspects of numerical analysis of suspended structures, in: 10th Nordic Seminar on Computational Mechanics, Tallinn, 1997, pp. 307-308.

[74] M.H. Triplett, W.P. Schonberg, Static and dynamic finite element analysis of honeycomb sandwich structures, Structural Engineering and Mechanics 6(1) (1998), 95-113.

[75] J.S. Turcotte, Analytical model for the forced response of cyclic structures, J. of Sound and Vibration 209(3) (1998), 531-536.

[76] H. Wang, K. Williams, Vibrational modes of thick cylinders of finite length, J. of Sound and Vibration 191(5) (1996), 955-971.

[77] Q.F. Wang, Spline finite member element method for vibration of thin-walled members with shear lag, J. of Sound and Vibration 206(3) (1997), 339-352.

[78] R.T. Wang, Vibration analysis of multispan beams subjected to moving loads using the finite element method, Transactions of the Chinese Institute of Engineers, Ser C 15(3) (1994), 229-235.

[79] P. Warnitchai et al., A non-linear dynamic model for cables and its application to a cable-structure system, J. of Sound and Vibration 187(4) (1995), 695-712.
[80] L.C. Wellford, K. Sadeghi, Modeling the behavior of HSC beam to column connections under cyclic loads, in: 15th Structures Congress, Portland, ASCE, 1997, pp. 1016-1020.

[81] F.W. Williams et al., Exact calculation of natural frequencies of repetitive structures, Structural Engineering and Mechanics 4(5) (1996), 553-568.

[82] E. Wittbrodt, S. Wojciech, Application of rigid finite element method to dynamic analysis of spatial systems, $J$. of Guidance, Control and Dynamics 18(4) (1995), 891-898.

[83] C.E. Woon, L.D. Mitchell, Temperature-induced variations in structural dynamic characteristics Part II: Analytical, Proceedings of the SPIE 2868(1996), 58-70.

[84] J.S. Wu, J.M. Chen, Dynamic analysis of spatial beam-like lattice girders, Computers and Structures 53(4) (1994), 961981.

[85] H. Yamaguchi, R. Adhikari, Energy-based evaluation of modal damping in structural cables with and without damping treatment, J. of Sound and Vibration 181(1) (1995), 7183.

[86] J.R. Yuan et al., Dynamic characteristics of composites with periodic and random structure, in: 1996 IEEE Ultrasonics Symposium, San Antonio, IEEE, 1996, pp. 949-954.

[87] V. Zeman, L. Kovar, Dynamical analysis of the large mechanical systems containing subsystems, ZAMM 78(S2) (1998) 833-834.

[88] P. Zeng, Composite element method for vibration analysis of structure, Part I: Principle and Co element (bar), J. of Sound and Vibration 218(4) (1998), 619-658.

[89] Q.J. Zhang, Finite element analysis of additive damping structures, in: 13th IMAC Conference, 1994, pp. 1006-1010.

[90] K. Zhu et al., Nonlinear dynamic analysis of lattice structures, Computers and Structures 52(1) (1994), 9-15.

[91] H. Zui et al., Practical formulas for estimation of cable tension by vibration method, J. of Structural Engineering, ASCE 122(6) (1996), 651-656.

[92] H. Zui et al., Basic study on simultaneous identification of cable tension and flexural rigidity by extended Kalman filter, Proceedings of Japan Society of Civil Engineers 556(I-38) (1997), 189-196.

\section{Ground structures}

\section{Trusses, frames, buildings and walls}

[93] S. Adhikari, C.S. Manohar, Dynamic analysis of framed structures with statistical uncertainties, Int.J. for Numerical Methods in Engineering 44(8) (1999), 1157-1178.

[94] S.S. Badie et al., Analysis of shear wall structures on elastic foundations, Computers and Structures 65(2) (1997), 213224.

[95] L. Billet et al., Updating a finite element model on the Hualien nuclear reactor building, in: 15th Int. Modal Analysis Conference, Orlando, IMAC, 1997, pp. 1924-1930.

[96] A.S. Cakmak et al., Dynamic response of Hagia Sophia, in: Worldwide Advances in Structural Concrete and Masonry Proc., Chicago, ASCE, 1996, pp. 200-210.

[97] R. Cantieni et al., Modal investigation of an office building floor, in: 16th Int. Modal Analysis Conference, Santa Barbara, 1998, pp. 1172-1178. 
[98] D. Capuani et al., Dynamic analysis of coupled shear wallframe systems, J. of Sound and Vibration 192(4) (1996), 867-883.

[99] L. Cavalera, B. Lipani, Dynamic behaviour of reinforced earth walls, in: ERES 96, Thessaloniki, 2, 1995, pp. 113-122.

[100] M.J. Chajes et al., Dynamic analysis of a ten-story reinforced concrete building using a continuum model, Computers and Structures 58(3) (1996), 487-498.

[101] M.J. Chajes et al., Dynamic analysis of tall building using reduced-order continuum model, J. of Structural Engineering, ASCE 122(11) (1996), 1284-1291.

[102] S.L. Chan, Large deflection dynamic analysis of space frames, Computers and Structures 58(2) (1996), 381-387.

[103] W.H. Chen, C.W. Wu, A spline wavelets element method for frame structures vibration, Computational Mechanics 16(1) (1995), 11-21.

[104] Y. Chen, Finite element analysis for walking vibration problems for composite precast building floors using ADINA: modeling, simulation, and comparison, Computers and Structures 72(1/3) (1999), 109-126.

[105] R.H. Cherng, Y.K. Wen, Reliability of uncertain nonlinear trusses under random excitation. I, J. of Engineering Mechanics, ASCE 120(4) (1994), 733-747.

[106] K.H. Chua et al., Building response due to subway train traffic, J. of Geotechnical Engineering, ASCE 121(11) (1995), 747-765.

[107] H. Dai, D. Ding, Dynamic study of ductile framed shearwalls, Structural Design of Tall Buildings 4(3) (1995), 229-240.

[108] H. Deng, L. Vu-Quoc, Dynamics of highly deformable sandwich frame structures, in: 11th Conference on Engineering Mechanics, Fort Lauderdale, FL, ASCE, 1996, pp. 11471150 .

[109] W. Dewulf, G. De Roeck, Identification of a floor consisting of precast hollow core units, in: 16th Int. Modal Analysis Conference, Santa Barbara, 1998, pp. 1165-1171.

[110] B.R. Ellis, T. Ji, Dynamic testing and numerical modelling of the Cardington steel framed building from construction to completion, Structural Engineering 74(11) (1996), 186-192.

[111] M.B. Fuchs, Unimodal formulation of the analysis and design problems for framed structures, Computers and Structures 63(4) (1997), 739-747.

[112] A. Hanajima et al., Flexibility analysis of a high-rise threedimensional building framework, in: 3rd World Congress on Computational Mechanics, Chiba, Japan, 1994, pp. A10-2.

[113] M.A. Hawwa, R.M. Brasil, Vibration confinement in trusses, J. of Engineering Mechanics, ASCE 122(3) (1996), 286-290.

[114] N. Inoue et al., Dynamic non-linear analysis of reinforced concrete shear wall by finite element method with explicit analytical procedure, Earthquake Engineering and Structural Dynamics 26(9) (1997), 967-986.

[115] M.R. Kianoush et al., Response of large panel precast wall systems: analysis and design, PCI J. 41(6) (1996), 90-108.

[116] M. Krawczuk, W.M. Ostachowicz, Bar finite element for vibration and buckling analysis of cracked truss constructions, J. of Theoretical and Applied Mechanics 32(2) (1994), 447462.

[117] J.S. Kuang, C.K. Chau, Free vibrations of stiffened coupled shear walls, Structural Design of Tall Buildings 7(2) (1998), 135-145

[118] J.S. Kuang, S.C. Ng, A continuous model for dynamic analysis of nonuniform wall-frame structures, in: 4th World Congress on Computational Mechanics, Buenos Aires, 1998, pp. 244.
[119] E. Levy, M. Eisenberger, Dynamic analysis of trusses including the effect of local modes, Structural Engineering and Mechanics 7(1) (1999), 81-94.

[120] G.Q. Li, B.S. Choo, Natural frequency evaluation of coupled shear walls, Structural Engineering 73(18) (1995), 301-304.

[121] P.L. Liu, C.C. Chen, Parametric identification of truss structures by using transient response, J. of Sound and Vibration 191(2) (1996), 273-287.

[122] X. Liu, A perturbation method for reduction of eigenvalue analysis of structures with large stiffnesses and small masses, Int. J. for Numerical Methods in Engineering 40(1/2) (1997), 2019-2035.

[123] Y. Liu et al., Dynamic analysis of spatial truss structures undergoing large overall motion, J. of Vibration Engineering 11(1) (1998), 18- 23.

[124] S.G. Mao, A.Y.T. Leung, Symplectic integration and nonlinear dynamic symmetry breaking of frames, Shock and Vibration 2(6) (1995), 481-492.

[125] S.R. Marur, T. Kant, A stress correction procedure for the analysis of inelastic frames under transient dynamic loads, Computers and Structures 50(5) (1994), 603-613.

[126] C.E.N. Mazzilli, R.M.L.R.F. Brasil, Effect of static loading on the nonlinear vibrations of a three-time redundant portal frame: analytical and numerical studies, Nonlinear Dynamics 8(3) (1995), 347-366.

127] O. Moller et al., Computational analysis of non linear dynamic behavior of reinforced concrete frames, in: 4th World Congress on Computational Mechanics, Buenos Aires, 1998, pp. 290.

[128] J.E. Mottershead, S. James, Updating parameters for the model of a three storey aluminum space frame, in: 16th Int. Modal Analysis Conference, Santa Barbara, 1998, pp. 8-11.

[129] B.A. Ovunc, Material and geometrical nonlinearity in the vibration of trusses, in: 3rd Joint Conference on Engineering Systems Design and Analysis PD 81, ASME, 1996, pp. 105112.

[130] O.A. Pekau et al., Displacement and natural frequencies of tall building structures by finite story method, Computers and Structures 54(1) (1995) 1-13.

[131] J. Riccius, Adaptive Methoden zur statischen und dynamischen Analyse von Flachentragwerken mit linearen Finite Elementen, Ph.D. Thesis, University of Karlsruhe, Germany, 1997

[132] D. Sachau, R. Schwertassek, Multibody simulation of a truss structure using finite element results, in: 3rd Int. Conference on Dynamics and Control of Structure in Space, SPACE, CMP, 1996, pp. 349-364.

[133] H. Singh et al., Inelastic dynamic response of reinforced concrete infilled frames, Computers and Structures 69(6) (1998), 685-693.

134] P.S. Skjaerbaek et al., Modal identification of a time-invariant 6-storey model test RC-frame from free decay tests using multi-variate models, in: 15th Int. Modal Analysis Conference, Orlando, IMAC, 1997, pp. 510-516.

[135] I. Takewaki, Hybrid inverse eigenmode problem for a shear building supporting a finite element subassemblage, $J V C / J$. of Vibration and Control 4(4) (1998), 347-360.

[136] A.M. Tarabia, R.Y. Itani, Static and dynamic modeling of light-frame wood buildings, Computers and Structures 63(2) (1997), 319-334.

[137] M. Tehranizadeh, Dynamic behaviour of tall building soilstructure interaction, in: Advances in Civil and Structural Engineering Computing for Practice, Civil-Comp, 1998, pp. 281-288. 
[138] P.C. Tsopelas et al., Nonlinear dynamic analysis of multiple building base isolated structures, Computers and Structures 50(1) (1994), 47-57.

[139] C. Van der Veen, J. Blaauwendraad, Non-linear dynamic analysis of a safety wall, in: Computing in Civil Engineering, ASCE, 1, 1995, pp. 613-620.

[140] R.T. Wang, J.L. Jeng, Dynamic analysis of a T-type Timoshenko frame to a moving load using finite element method, $J$. of the Chinese Institute of Engineers 19(3) (1996), 409-416.

[141] Y. Wang et al., Simplified method for evaluating fundamental natural frequency of shear wall with multiple bands of openings, J. of Sound and Vibration 221(2) (1999), 334-341.

[142] X.C. Xie, Vibration mode localization in disordered large planar lattice trusses, Chaos, Solitons and Fractals 8(3) (1997), 433-454.

[143] T. Yamao et al., Dynamic characteristics of curved pair members tied with struts and truss members, J. of Constructional Steel Research 46 (1/3) (1998), 451.

\section{Bridges}

[144] H. Alaylioglu, A. Alaylioglu, Dynamic structural assessment of a highway bridge via hybrid FE model and in situ testing, Computers and Structures 63(3) (1997), 439-453.

[145] D.M. Armstrong et al., Modal analysis for masonry arch bridge spandrel wall separation identification, NDT \& E Int. 28(6) (1995), 377-386.

[146] T.A. Ballard, H. Sedarat, SR5 Lake Washington ship canal bridge pushover analysis, Computers and Structures 72(1/3) (1999), 63-80.

[147] J.M.W. Brownjohn, Vibration characteristics of a suspension footbridge, J. of Sound and Vibration 202(1) (1997), 29-46.

[148] D. Bruno, A. Leonardi, Natural periods of long-span cablestayed bridges, J. of Bridge Engineering 2(3) (1997), 105115 .

[149] K. Chompooming, Bridge dynamic interaction and optimum design, Ph.D. Thesis, Utah State University, 1994.

[150] K. Chompooming, M. Yener, The influence of roadway surface irregularities and vehicle deceleration on bridge dynamics using the method of lines, J. of Sound and Vibration 183(4) (1995), 567-589.

[151] P. Clemente et al., Experimental modal analysis of the Garigliano cable-stayed bridge, Soil Dynamics and Earthquake Engineering 17 (7/8) (1998), 485-493.

[152] M. Fafard et al., A general multi-axle vehicle model to study the bridge-vehicle interaction, Engineering Computations 14(5) (1997), 491-508.

[153] M. Fafard et al., Dynamic analysis of existing continuous bridge, J. of Bridge Engineering 3(1) (1998), 28-37.

[154] C.R. Farrar, T.A. Duffey, Bridge modal properties using simplified finite element analysis, J. of Bridge Engineering 3(1) (1998), 38-46.

[155] A. Fasana et al., Analysis of a motorway bridge under random traffic excitation, in: 15th Int. Modal Analysis Conference, Orlando, IMAC, 1997, pp. 293-300.

[156] O. Friberg, An integrated environment for simulations of heavy vehicles riding over flexible bridges, in: 4th World Congress on Computational Mechanics, Buenos Aires, 1998, pp. 442.

[157] C. Gentile, F. Martinez, Dynamic investigation of a repaired cable-stayed bridge, Earthquake Engineering and Structural Dynamics 26(1) (1997), 41-59.
[158] H.W. George, K. Hassan, Effect of material of deck response of cable-stayed bridges to live loads, J. of Constructional Steel Research 46(1/3) (1998), 50-51.

[159] M.F. Green, D. Cebon, Dynamic response of highway bridges to heavy vehicle loads: theory and experimental validation, J. of Sound and Vibration 170(1) (1994), 51-78.

[160] I.E. Harik et al., 3-D dynamic analysis of the Brent-Spence through-truss bridge, in: Structural Congress XII, Atlanta, ASCE, 1994, pp. 1112-1117.

[161] I.E. Harik et al., Free and ambient vibration of Brent-Spence bridge, J. of Structural Engineering, ASCE 123(9) (1997), 1262-1268.

[162] K. Henchi et al., Dynamic analysis of road bridges for bridgevehicles. I- Numerical aspects, Canadian J. of Civil Engineering 25(1) (1998) 161-173.

[163] K. Henchi et al., Dynamic analysis of road bridges for bridge vehicles. II- Application to Senneterre bridge in Quebec, Canadian J. of Civil Engineering 25(1) (1998), 174-187.

[164] D. Huang et al., Vibration of horizontally curved box girder bridges due to vehicles, Computers and Structures 68(5) (1998), 513-528.

[165] J.L. Humar, A.H. Kashif, Dynamic response analysis of slabtype bridges, J. of Structural Engineering, ASCE 121(1) (1995), 48-62.

[166] E.S. Hwang, S.P. Chang, Dynamic loads for continuous span bridge, in: Structural Safety and Reliability, G I Schueller, ed, Balkema, 1994, pp. 1461-1464.

[167] A. Jutila, A. Tesar, Non-linear damping of slender wood bridges, Computers and Structures 61(4) (1996), 657-664.

[168] J.M. Ko et al., Modal analysis of suspension bridge deck units in erection stage, Engineering Structures 20(12) (1998), 1102-1112.

[169] J.W. Kou, J.T. DeWolf, Vibrational behavior of continuous span highway bridge- influencing variables, J. of Structural Engineering, ASCE 123(3) (1997), 333-344.

[170] S.S. Law et al., Evaluation of load carrying capacity of bridge deck from vibrational response, in: Structural Safety and Reliability, G.I. Schueller, ed, Balkema, 1994, pp. 903-910.

[171] J.L. Lilien, A.P. Da Costa, Vibration amplitudes caused by parametric excitation of cable stayed structures, J. of Sound and Vibration 174(1) (1994), 69-90.

[172] C. Liu, Q. Qin, Sensitivities of natural modes of suspension bridges to structural parameters, J. of Tsinghua University of Science and Technology 38(12) (1998), 48-51.

[173] M.E. Mabsout et al., Influence of sidewalks and railings on wheel load distribution in steel girder bridges, J. of Bridge Engineering 2(3) (1997), 88-96.

[174] J.H.G. Macdonald et al., Modal analysis of a partially constructed cable-stayed bridge, in: 16th Int. Modal Analysis Conference, Santa Barbara, 1998, pp. 1367-1373.

[175] S. Marchesiello et al., Dynamics of multi-span continuous straight bridges subject to multi-degrees of freedom moving vehicle excitation, J. of Sound and Vibration 224(3) (1999), 541-561.

[176] V. Mermertas, Dynamic interaction between the vehicle and simply supported curved bridge deck, Computer Methods in Applied Mechanics and Engineering 162(1/4) (1998), 125131.

[177] R.M. Mutobe, T.R. Cooper, Nonlinear analysis of a large bridge with isolation bearings, Computers and Structures 72(1/3) (1999), 279-292.

[178] W.N. Patten et al., Modal testing of the I-35 Walnut Creek bridge, in: 16th Int. Modal Analysis Conference, Santa Barbara, 1998, pp. 429-435. 
[179] P. Paultre et al., Dynamic testing procedures for highway bridges using traffic loads, J. of Structural Engineering, ASCE 121(2) (1995), 362-376.

[180] P. Paultre et al., Dynamic investigation of Beauharnois suspension bridge, in: 16th Int. Modal Analysis Conference, Santa Barbara, 1998, pp. 1353-1356.

[181] S.J. Pietrzko et al., Identification of a reference mathematical model of an arch bridge using full-scale forced modal testing and finite element modeling, Proceedings of the SPIE, 2719(1996), 180-191.

[182] R.L. Pimentel, P. Waldron, Validation of the pedestrian load model through the modal testing of a composite footbridge, in: 15th Int. Modal Analysis Conference, Orlando, IMAC, 1997, pp. 286-292.

[183] A.B. Sabir et al., Natural frequencies of arch bridges with slab decks by the finite element method, Thin-Walled Structures 18(1) (1994), 31-46.

[184] O.S. Salawu, C. Williams, Theoretical and experimental vibration analysis of a reinforced concrete bridge, in: 15th Int Modal Analysis Conference, Orlando, IMAC, 1997, pp. 278285.

[185] O.S. Salawu et al., Comparison of results from vibration testing and finite element analysis of a highway bridge, in: 2nd Int. Conference on Computational Structural Technology, Athens, 1994.

[186] K. Sennah, J.B. Kennedy, Vibrations of horizontally curved continuous composite cellular bridges, Canadian J. of Civil Engineering 25 (1) (1998), 139-150.

[187] K.M. Sennah, J.B. Kennedy, Free-vibration response of simply-supported composite concrete deck-steel multi-cell bridges, in: 1997 Annual Conference of the Canadian Society of Civil Engineers, Sherbrooke, 4, 1997, pp. 11-20.

[188] J. Senthilvasan et al., Bridge-vehicle interaction in curved box girder bridges, Microcomputers in Civil Engineering 12(3) (1997), 171-182.

[189] U. Starossek, Simplified flutter prediction for bridges with bluff cross-section, Structural Engineering Review 6(1) (1994), 35-38.

[190] M. Tanabe et al., Modal transformation method for dynamic interaction analysis of high-speed train, rail and bridge, in: 3rd World Congress on Computational Mechanics, Chiba, Japan, 1994, pp. A4-4.

[191] M. Tanabe et al., Efficient numerical method for dynamic interaction analysis of high-speed Shinkansen vehicles, rail, and bridge, in: ASME Int. Computers in Engineering Conference and Exhibition, ASME, 1994, pp. 567- 572.

[192] J.W. Tedesco et al., Finite element method analysis of bridge girder-diaphragm interaction, Computers and Structures 56(2/3) (1995), 461-473.

[193] J.W. Tedesco et al., Finite element method analysis of a concrete bridge repaired with fiber reinforced plastic laminates, Computers and Structures 72(1/3) (1999), 379-407.

[194] M.M.A. Wahab, G. DeRoeck, Dynamic testing of prestressed concrete bridges and numerical verification, J. of Bridge Engineering 3(4) (1998) 159-169.

[195] M.L. Wang et al., Dynamic characterization of a long span bridge: a finite element based approach, Soil Dynamics and Earthquake Engineering 16(7/8) (1997), 503-512.

[196] Y.C. Wang, C.H. Hua, Effects of number of cables for modal analysis of cable-stayed bridges, in: 16th Int. Modal Analysis Conference, Santa Barbara, 1998, pp. 1374-1380.

[197] J.S. Wu, P.Y. Shih, Moving-load-induced vibrations of a moored floating bridge, Computers and Structures 66(4) (1998), 435-461.
[198] Y.L. Xu et al., Modal analysis of tower-cable system of Tsing Ma long suspension bridge, Engineering Structures 19(10) (1997), 857-867.

[199] Y.L. Xu et al., Vibration studies of Tsing Ma suspension bridge, J. of Bridge Engineering 2(4) (1997), 149-156.

[200] Y.L. Xu et al., Buffeting analysis of long span bridges: a new algorithm, Computers and Structures 68(4) (1998), 303-313.

[201] S.D. Xue et al., Modal characteristics of tower-cable system in construction state of suspension bridge, in: 15th Int. Modal Analysis Conference, Orlando, IMAC, 1997, pp. 1911-1917.

[202] Y. Yamada et al., Computational mechanics applied to the design and construction of Akashi Kaikyo bridge, in: $3 r d$ World Congress on Computational Mechanics, Chiba, Japan, 1994, pp. N4-1.

[203] F. Yang, G.A. Fonder, Dynamic response of cable-stayed bridges under moving loads, J. of Engineering Mechanics, ASCE 124(7) (1998), 741-747.

[204] Y.B. Yang, B.H. Lin, Vehicle-bridge interaction analysis by dynamic condensation method, J. of Structural Engineering, ASCE 121(11) (1995), 1636-1643.

[205] W.H.P. Yen et al., Modal identification of a cable-stayed bridge, in: 11th Conference on Engineering Mechanics, Fort Lauderdale, FL, ASCE, 1996, pp. 600-603.

[206] M. Yener, K. Chompooming, Numerical method of lines for analysis of vehicle-bridge dynamic interaction, Computers and Structures 53 (3) (1994), 709-726.

[207] M. Zaman et al., Dynamic response of cable-stayed bridges to moving vehicles using the structural impedance method, Applied Mathematical Modelling 20(12) (1996), 877-889.

[208] E.T. Zechlin, J. Chai, Nonlinear dynamic analysis of large diameter pile foundations for the bay bridge, in: Conference on Geotechnical Earthquake Engineering and Soil Dynamics 3, Seattle, ASCE, 1998, pp. 1223-1234.

[209] H. Zhu, J. Tang, Three dimensional finite element model of cable-stayed bridges for dynamic analysis, J. of Vibration Engineering 11(1) (1998), 121-126.

\section{Dams}

[210] R. Cantieni et al., Modal investigation of a dam, in: 16th Int. Modal Analysis Conference, Santa Barbara, 1998, pp. 11511155.

[211] J.M. De Araujo, A.M. Awruch, Probabilistic finite element analysis of concrete gravity dams, Advances in Engineering Software 29(2) (1998), 97-104.

[212] X. Du et al., Dynamic response analysis of high arch damwater-foundation system, in: 11th Conference on Engineering Mechanics, Fort Lauderdale FL, ASCE, 1996, pp. 987988.

[213] F. Guan, I.D. Moore, New techniques for modeling reservoirdam and foundation-dam interaction, Soil Dynamics and Earthquake Engineering 16(4) (1997), 285-293.

[214] X. Li et al., Finite element analysis of dam-reservoir systems using an exact far-boundary condition, Computers and Structures 60(5) (1996), 751-762.

[215] R.A. Mir, C.A. Taylor, Investigation into the base sliding response of rigid concrete gravity dams to dynamic loading, Earthquake Engineering and Structural Dynamics 25(1) (1996), 79-98.

[216] C.M.D. Moorthy, J.N. Reddy, Three-dimensional vibrations of inflatable dams, Thin-Walled Structures 21(4) (1995), 291-306. 
[217] D.A.P. Murrugarra et al., Earth dams under static and dynamic loadings, in: 4th World Congress on Computational Mechanics, Buenos Aires, 1998, pp. 1090.

[218] G.V. Mysore et al., Vibration analysis of single-anchor inflatable dams, in: ASME Int. Mechanical Engineering Congress and Expo. AD 53-2, ASME, 1997, pp. 119-124.

[219] T. Ohmachi, S. Kataoka, Evaluation of dynamic interaction effects of 2D dam-foundation-reservoir systems, Proceedings of Japan Society of Civil Engineers 519(I-32) (1995), 199-209.

[220] A.C. Singhal, M.S. Zuroff, Dynamic analysis of dams with nonlinear slip-joints, Soil Dynamics and Earthquake Engineering 17(3) (1998), 185-196.

[221] M. Ueda et al., Simulation analysis of forced vibration response of arch dam, Proceedings of Japan Society of Civil Engineers 501(29) (1994), 203-212.

[222] M. Ueda et al., Simulation analysis of dynamic water pressure and displacements measured on forced vibration test of arch dam, Proceedings of Japan Society of Civil Engineers 605(I45) (1998), 15-28.

[223] P.K. Woodward, D.V. Griffiths, Non-linear dynamic analysis of the Long Valley dam, in: Computers Methods and Advances in Geomechanics, H J Siriwardane, ed, Balkema, 1994, pp. 1005-1010.

[224] P.K. Woodward, D.V. Griffiths, Influence of viscous damping in the dynamic analysis of an earth dam using simple constitutive models, Computers and Geotechnics 19(3) (1996), 245-263.

[225] C.B. Zhao, G.P. Steven, Asymptotic formulae for correcting finite element predicted natural frequencies of gravity and embankment dams, Soil Dynamics and Earthquake Engineering 15(3) (1996), 161-170.

\section{Piles, foundations and underground structures}

[226] R.I. Borja et al., Nonlinear lateral, rocking, and torsional vibration of rigid foundations, J. of Geotechnical Engineering, ASCE 120(3) (1994) 491-513.

[227] M.F. Bransby, M.F. Randolph, Effect of skirted foundation shape on response to combined V-M-H loadings, in: 8 th Int. Offshore and Polar Engineering Conference, Montreal, 1998, pp. 543-548.

[228] J.P. Burr et al., Dynamic response of laterally excited pile groups, J. of Geotechnical and Geoenvironmental Engineering 123(1) (1997), 1-8.

[229] R.A. Carman, A.R. Crockett, Finite element vibration analysis of subway structures, in: 1996 National Conference on Noise Control Engineering, Bellevue, 1996, pp. 899-904.

[230] A.J. Deeks, M.F. Randolph, Simple model for inelastic footing response to transient loading, Int. J. for Numerical and Analytical Methods in Geomechanics 19(5) (1995), 307-329.

[231] X. Du et al., Dynamic response analysis of high arch damwater- foundation system, in: 11th Conference on Engineering Mechanics, Fort Lauderdale, FL, ASCE, 1996, pp. 987988.

[232] W. Gardien et al., Finite element wave propagation models, in: 2nd European LS-DYNA Conference, Gothenburg, 1999, pp. D33-42.

[233] N.F. Grace, M.R. Romzek, Resonance/vibration problem of deep foundation, Concrete Int. 19(1) (1997), 26-32.

[234] F. Guan, I.D. Moore, New techniques for modeling reservoirdam and foundation-dam interaction, Soil Dynamics and Earthquake Engineering 16(4) (1997), 285-293.
[235] Y.C. Han, Dynamic vertical response of piles in nonlinear soil, J. of Geotechnical and Geoenvironmental Engineering 123(8) (1997), 710-716.

[236] S.T. Liao, J.M. Roesset, Dynamic response of intact piles to impulse loads, Int. J. for Numerical and Analytical Methods in Geomechanics 21(4) (1997), 255-275.

[237] W. Liu, M. Novak, Dynamic response of single piles embedded in transversely isotropic layered media, Earthquake Engineering and Structural Dynamics 23(11) (1994), 12391257.

[238] J.W. Meek, J.P. Wolf, Cone models for embedded foundation, J. of Geotechnical Engineering, ASCE 120(1) (1994), 60-80.

[239] M.K.A. Molla, D.P. Ray, Analysis of flexible rectangular raft foundations under dynamic loading, Computers and Structures 52(5) (1994), 1079-1091.

[240] T. Ohmachi, S. Kataoka, Evaluation of dynamic interaction effects of 2D dam-foundation-reservoir systems, Proceedings of Japan Society of Civil Engineers 519(I-32) (1995), 199-209.

[241] C.Y. Ou, J.C. Cherng, Effect of tail void closure on ground movement during shield tunnelling in sandy soil, Geotechnical Engineering 26 (1) (1995), 17-32.

[242] H.G. Poulos, L.T. Chen, Pile response due to unsupported excavation-induced lateral soil movement, Canadian Geotechnical J. 33 (4) (1996), 670-677.

[243] J. Qian, D.E. Beskos, Harmonic wave response of two 3 D rigid surface foundations, Soil Dynamics and Earthquake Engineering 15(2) (1996), 95-110.

[244] C. Ramshaw et al., Computed ground waves due to piling, in: Conference on Geotechnical Earthquake Engineering and Soil Dynamics 3, Seattle, ASCE, 1998, pp. 1484-1495.

[245] R.V. Rao, N.S.V.K. Rao, Dynamic analysis of foundations using infinite elements, in: Computers Methods and Advances in Geomechanics, H J Siriwardane, ed, Balkema, 1994, pp. 961-966.

[246] N.G. Sarigul, Parametric studies on vertical boundary location in dynamic finite element analyses, Computers and Structures 62(3) (1997), 595-601.

[247] S.J. Serhan, Dynamics of nuclear power plant structures with foundation interaction, in: Proceedings of Structural Congress '94, Atlanta, ASCE, 1994, pp. 55-60.

[248] B.H. Thacker et al., Computational model comparisons with static and dynamic experiments of tunnels in limestone, in: Numerical Implementation of Applied Constitutive Models FEM, AMD 213, ASME, 1995, pp. 95-114.

[249] H. Wang, H. Takemiya, Dynamic responses of tunnels to incident P, SV and Rayleigh waves by combined finite element method and try function method, in: Computers Methods and Advances in Geomechanics, H J Siriwardane, ed, Balkema, 1994, pp. 999-1004.

[250] R.P. West, M.N. Pavlovic, Finite element model sensitivity in the vibration of partially embedded beams, Int. J. for $\mathrm{Nu}$ merical Methods in Engineering 44(4) (1999), 517-533.

[251] G.X. Wu, W.D.L. Finn, Dynamic elastic analysis of pile foundations using finite element method in the frequency domain, Canadian Geotechnical J. 34(1) (1997), 34-43.

[252] G.X. Wu, W.D.L. Finn, Dynamic nonlinear analysis of pile foundations using finite element method in the time domain, Canadian Geotechnical J. 34(1) (1997), 44-52.

[253] S. Yamamoto et al., Dynamic and static displacement property of rigid foundation on weathered rock by field test, Proceedings of Japan Society of Civil Engineers 554(37) (1996), 31-45. 
[254] C.H. Yuan, Nonlinear analysis of pile behaviour under dynamic and creep conditions, in: Computers Methods and Advances in Geomechanics, H J Siriwardane, ed, Balkema, 1994, pp. 2409-2414.

[255] E.T. Zechlin, J. Chai, Nonlinear dynamic analysis of large diameter pile foundations for the bay bridge, in: Conference on Geotechnical Earthquake Engineering and Soil Dynamics 3, Seattle, ASCE, 1998, pp. 1223-1234.

[256] T. Zheng, Dynamic behavior of piles embedded in transversely isotropic layered media, Acta Mechanica Sinica 13(3) (1997), 241-252.

\section{Pavements}

[257] M.L.B.C. Antunes, C.A.B. Pina, Dynamic analysis of road pavements, in: 3rd World Congress on Computational Mechanics, Chiba, Japan, 1994, pp. A4-6.

[258] M.A. Bhatti, J.W. Stoner, Nonlinear pavement distress model using dynamic vehicle loads, J. of Infrastructure Systems 4(2) (1998), 71-78.

[259] K. Chatti et al., Dynamic model for analysis of concrete pavements, in: Structural Congress XII, Atlanta, ASCE, 1994, pp. 984-989.

[260] K. Chatti et al., Dynamic finite-element analysis of jointed concrete pavements, Transportation Research Record No 1449 (1994) 79-90.

[261] C.C. Chiang et al., Effects of irregularities on the dynamic response of pavements in non-destructive tests, in: Computers Methods and Advances in Geomechanics, H J Siriwardane, ed, Balkema, 1994, pp. 1447-1452.

[262] E.H. Guo, J.L. Rice, Effects of slab size on critical responses in airport concrete pavements, in: Airfield Pavement Conference, Seattle, ASCE, 1997, pp. 320-334.

[263] D.J. Kirkner et al., Numerical simulation of permanent deformation in flexible pavement systems subjected to moving loads, in: 11th Conference on Engineering Mechanics, Fort Lauderdale, FL, ASCE, 1996, pp. 430-433.

[264] J. Mallela, K.P. George, Three-dimensional dynamic response model for rigid pavements, Transportation Research Record No 1448 (1994) 92-99.

[265] M. Parvini, D.F.E. Stolle, Interpretation of pavement deflection measurement data using an elastodynamic stochastic approach, Canadian J. of Civil Engineering 25(1) (1998), 151160.

[266] M.R. Taheri, M.M. Zaman, Effects of a moving aircraft and temperature differential on response of rigid pavements, Computers and Structures 57(3) (1995), 503-511.

[267] W. Uddin et al., Finite element simulation of pavement discontinuities and dynamic load response, Transportation Research Record No 1448 (1994), 100-106.

[268] S.M. Zaghloul et al., Dynamic analysis of FWD loading and pavement response using a three-dimensional dynamic finite element program, ASTM Special Technical Publ. No 1198 (1994), 125-138.

[269] S.M. Zaghloul et al., Use of three-dimensional, dynamic, nonlinear analysis to develop load equivalency factors for composite pavements, Transportation Research Record No 1449 (1994), 199-208.

[270] S.M. Zaghloul et al., Evaluation of heavy load damage effect on concrete pavements using three-dimensional, nonlinear dynamic analysis, Transportation Research Record No 1449 (1994) 123-133.

\section{Other structures}

[271] H. Aoi et al., Vibration analysis of FBR Monju's damaged thermowell, in: 4th World Congress on Computational Mechanics, Buenos Aires, 1998, pp. 225.

[272] W.E. Daniel, C.A. Taylor, Full-scale dynamic testing and analysis of a reservoir intake tower, Earthquake Engineering and Structural Dynamics 23(11) (1994), 1219-1237.

[273] Y.M. Desai et al., Perturbation-based finite element analyses of transmission line, J. of Sound and Vibration 191(4) (1996), 469-489.

[274] P.W. Elliot et al., Static, modal and transient analysis of a hardwood athletic flooring system using finite elements, ASAE Annual Int. Meeting, Minneapolis, 1 1997, paper no. 973122 .

[275] I. Enevoldsen, K.J. Mork, Effects of a vibration mass damper in a wind turbine tower, Mechanics of Structures and Machines 24(2) (1996), 155-187.

[276] S. Erlingsson, A. Bodare, Live load induced vibrations in Ullevi stadium- dynamic soil analysis, Soil Dynamics and Earthquake Engineering 15(3) (1996), 171-188.

[277] N.B. Kahla, Nonlinear dynamic response of a guyed tower to a sudden guy rupture, Engineering Structures 19(11) (1997), 879-890.

[278] W. Liao, G. Fu, The finite element analysis of a light construction elevator tower, in: 1st Int. Conf. on Engineering Computation and Computer Simulation, Changsha, China, 1995, pp. 370-374.

[279] M.K.S. Madugula et al., Dynamic response of guyed masts, Engineering Structures 20(12) (1998), 1097-1101.

[280] T. Matsuda et al., Shaking table test and dynamic effective stress analysis of light structure under saturated sandy ground, in: Computers Methods and Advances in Geomechanics, H J Siriwardane, ed, Balkema, 1994, pp. 935-941.

[281] G. Monti et al., Finite element for anchored bars under cyclic load reversals, J. of Structural Engineering, ASCE 123(5) (1997), 614-623.

[282] K.K. Muraleetharan et al., Fully coupled non-linear dynamic analysis procedure and its verification using centrifuge test results, Int. J. for Numerical and Analytical Methods in Geomechanics 18(5) (1994), 305-325.

[283] K. Nagamani, C. Ganapathy, Finite element analysis of nonlinear dynamic response of articulated towers, Computers and Structures 59(2) (1996), 213-223.

[284] M. Ostendorp, Evaluation of dynamic analysis results using full-scale lattice tower tests, in: 14th Structures Congress, Chicago, ASCE, 1996, pp. 518-525.

[285] M. Ostendorp, Damping characteristics of a steel lattice structure, in: 15th Structures Congress, Portland, ASCE, 1997, pp. 358-362.

[286] B. Peeters, G. De Roeck, Stochastic subspace system identification of a steel transmitter mast, in: 16th Int. Modal Analysis Conference, Santa Barbara, 1998, pp. 130-136.

[287] A. Recuero et al., Uneven dynamic response of floors in a sports pavilion, Computers and Structures 55(1) (1995), 185-189.

[288] P. Reynolds et al., Modal testing of a 150-tone concrete slab incorporating a false floor system, in: 16th Int. Modal Analysis Conference, Santa Barbara, 1998, pp. 1574-1577.

[289] C.T.F. Ross, Vibration of thin-walled domes under external hydrostatic pressure, in: Advances in Computational Structural Mechanics, BHV Topping, ed, Civil-Comp, 1998, pp. 147-153. 
[290] H. Saal et al., Dynamical tests of crane runaways and their supporting structures under vertical moving load, Stahlbau 65(1) (1996), 10-18.

[291] A.R. Selby, J.M. Wilson, Dynamic behaviour of masonry church bell towers, in: Worldwide Advances in Structural Concrete and Masonry Proc., Chicago, ASCE, 1996, pp. 188-199.

[292] S.J. Serhan, Dynamic behavior and identification of failure modes of cooling towers, in: 56th Annual American Power Conference, Chicago, 1994, pp. 246-249.

[293] H. Takabatake, A. Mizuki, Simplified dynamic analysis of slender tapered thin-walled towers with additional mass and rigidity, Structural Engineering and Mechanics 3(1) (1995), 61-74.

[294] E. Van Bokhorst et al., Elimination of pulsations in a chemical plant- a combination of measurements calculations and scale model experiments, in: ASME Int. Mechanical Engineering Congress and Expo., AD 53-2, ASME, 1997, pp. 533-537.

[295] Y.M.F. Wahba et al., Natural frequencies of guyed communication towers, in: 15th Structures Congress, Portland, ASCE, 1997, pp. 544-548.

\section{Ocean and coastal structures}

[296] H.C. Chen, W.M. Lin, Numerical simulation of wave effects on a combined breakwater and platform configuration, in: OTRC Symposium on Ocean Wave Kinematics and Dynamic Loads, Houston, ASCE, 1998, pp. 116-125.

[297] J. Dalheim, Numerical procedure for predicting transverse forces on a body submitted to lock-in motion, Int. J. of Offshore and Polar Engineering 7(4) (1997), 269-276.

[298] A.S. Duggal, J.M. Niedzwecki, Estimation of flexible cylinder displacements in wave-basin experiments, Experimental Mechanics 35(3) (1995), 233-244.

[299] O.I. Eide et al., Recent developments in reassessment of jacket structures under extreme storm cyclic loading, Part I: Overview, in: Proceedings of Int. Conference on Offshore Mechanics and Arctic Engineering, OMAE, 1, ASME, 1995, pp. 105-112.

[300] A.C. Fernandes et al., Flexible and rigid risers hydrodynamic coefficients by model testing and finite element method, in: 10th Int. Symposium on Offshore Engineering, Rio de Janeiro, 1997, pp. 377-392.

[301] M. Fujikubo et al., Dynamic response analysis of very large floating structures in waves using one-dimensional finite element model, in: Int. Conference on Offshore Mechanics and Arctic Engineering, Yokohama, ASME, 1997, pp. 107-114.

[302] J.S. Goo et al., Structural response analysis of tension leg platforms including hydrodynamic interactions in waves, in: 16th Int. Conference on Offshore Mechanics and Arctic Engineering, Yokohama, ASME, 1997, pp. 141-149.

[303] T. Hamamoto et al., Hybrid dynamic analysis of large tension leg floating structures using brick elements, in: 16th Int. Conference on Offshore Mechanics and Arctic Engineering, Yokohama, ASME, 1997, pp. 195-202.

[304] T.D. Hanson, A.U. Nilsen, Assessment of a probabilistic approach for design of dynamic flexible risers, in: 4th Int. Offshore and Polar Engineering Conference, Osaka, 1994, pp. 238-245.

[305] H. Hartnett et al., Modal analysis of an existing offshore platform, Engineering Structures 19(6) (1997), 487-498.
[306] M. Hartnett, P. Mitchell, Effects of structure spatial extent on frequency domain analysis of offshore jacket platforms, in: Advances in Civil and Structural Engineering Computing for Practice, Civil-Comp, 1998, pp. 351-358.

[307] T.D. Hien et al., Spectral analysis of superstructures excited by deck motion, in: 2nd Int. Conference on Marine Technology, ODRA'97, Szczecin, 1997, pp. 117-126.

[308] B.A. Izzuddin, D.L. Smith, Response of offshore structures to explosion loading, in: 6th Int. Offshore and Polar Engineering Conference, Los Angeles, 1, 1996, pp. 323-330.

[309] C. Kalliontzis, Numerical simulation of submarine pipelines in dynamic contact with a moving seabed, Earthquake Engineering and Structural Dynamics 27(5) (1998), 465-486.

[310] W. Ke et al., Modal analysis of oilfield derrick structure, in: 15th Int. Modal Analysis Conference, Orlando, IMAC, 1997, pp. 1871-1877.

[311] B.J. Leira et al., Reliability assessment of marine structures by long-term response analysis and importance sampling, in: Structural Safety and Reliability, G I Schueller, ed, Balkema, 1994, pp. 505-510.

[312] Y. Liu, L. Bergdahl, Improvements on Huse's model for estimating mooring cable induced damping, in: 17th Int. Conference on Offshore Mechanics and Arctic Engineering, Lisbon, OMAE, 1998, pp. 1-7.

[313] W. Ma, W.C. Webster, Dynamics of falling chain: a rigid-link model, in: 16th Int. Conference on Offshore Mechanics and Arctic Engineering, Yokohama, ASME, 1997, pp. 253-261.

[314] C. Magluta et al., Modal parameter estimation of a small scale model of an offshore platform: a comparison of two different algorithms, in: 10th Int. Symposium on Offshore Engineering, Rio de Janeiro, 1997, pp. 457-469.

[315] I.H.P. Mamaghani et al., Inelastic large deflection analysis of structural steel members under cyclic loading, Engineering Structures 18(9) (1996), 659-668.

[316] M.E. Martinez et al., In-service modal testing of a $330 \mathrm{~m}$ refinery pier, in: 15th Int. Modal Analysis Conference, Orlando, IMAC, 1997, pp. 1158-1164.

[317] U.A. Morsy, Non-linear finite element modelling of dynamic loads on offshore structures, Ph.D. Thesis, University of Calgary, Canada, 1995.

[318] U.A. Morsy, T.G. Brown, Three-dimensional non-linear finite element model for the Molikpaq, Gulf's mobile caisson, Computers and Structures 60(4) (1996), 541-560.

[319] B.A. Nedushan, L.E. Chouinard, Non-linear analysis of offshore platforms- a case study of two platforms during hurricane Andrew, in: 8th Int. Offshore and Polar Engineering Conference, Montreal, 1998, pp. 371-374.

[320] R.J. Ramos, J. Zhang, Prediction of low-frequency offshore structure response to irregular waves using linear and highorder wave theories, in: 1996 SPE Int. Petroleum Conference and Exhibition, Villahermose, 1996, pp. 339-351.

[321] Z. Ran, M.H. Kim, Nonlinear coupled responses of a tethered spar platform in waves, in: 6th Int. Offshore and Polar Engineering Conference, Los Angeles, 1, 1996, pp. 281-288.

[322] C. Ratsivalaka et al., Influence of mooring dynamics on current records, Oceans Conference Records 3(1994), 28-33.

[323] S.A. Sannasiraj et al., Response amplitude operator of motions in regular and random oblique waves, 17th Int. Conference on Offshore Mechanics and Arctic Engineering, Lisbon, OMAE, 1998, pp. 1-7.

[324] S.A. Sannasiraj et al., Mooring forces and motion responses of pontoon-type floating breakwaters, Ocean Engineering 25(1) (1998), 27-48. 
[325] S.A. Sannasiraj et al., Hydrodynamic behavior of long floating structures in directional seas, Applied Ocean Research 33(2) (1996), 429-434.

[326] G.K. Schleyer, D. Campbell, Development of simplified analytical methods for predicting the response of offshore structures to blast and fire loading, Marine Structures 9(10) (1996), 949-970.

[327] I. Senjanovic, J. Parunov, Dynamic analysis of tower buoy in irregular waves, in: 8th Int. Offshore and Polar Engineering Conference, Montreal, 1998, pp. 309-316.

[328] M. Takaki, X. Gu, Motion response of a mat-like floating structure in waves, in: 16th Int. Conference on Offshore Mechanics and Arctic Engineering, Yokohama, ASME, 1997, pp. 147-154.

[329] T. Tanabe et al., Dynamic wave interaction analysis of floating elastic plates, in: 7th Int. Offshore and Polar Engineering Conference, Honolulu, 1997, pp. 245-252.

[330] K. Tornes et al., Pipeline structural response to fishing gear pull-over loads by 3D transient FEM analysis, in: 8th Int. Offshore and Polar Engineering Conference, Montreal, 2, 1998, pp. 134-142.

[331] C.P. Vendhan et al., Dynamic analysis of buoyant elastic framed structures, in: 17th Int. Conference on Offshore Mechanics and Arctic Engineering, Lisbon, OMAE, 1998, pp. 1-8.

[332] P.H. Wang et al., Finite element analysis of a threedimensional underwater cable with time-dependent length, J. of Sound and Vibration 209(2) (1998), 223-249.

[333] M.S. Williams et al., Non-linear dynamic analysis of offshore jack-up units, Computers and Structures 69(2) (1998), 171180.

[334] M.S. Williams et al., Parametric study of the nonlinear dynamic behavior of an offshore jack-up unit, Engineering Structures 21(5) (1999), 383-394.

[335] S.R. Winterstein, R. Torhaug, Extreme jack-up response: simulation and nonlinear analysis methods, J. of Offshore Mechanics and Arctic Engineering, ASME 118(2) (1996), $103-108$.

[336] Y. Yasuzawa et al., Dynamic response of a large flexible floating structure in regular waves, in: 16th Int. Conference on Offshore Mechanics and Arctic Engineering, Yokohama, ASME, 1997, pp. 187-194.

\section{Mobile structures}

\section{Aircraft, helicopters and aerospace structures}

[337] W.G. Abdelrahman, H.M. Negm, Analysis of composite swept wing structures, J. of Engineering and Applied Science 44(2) (1997), 325-338.

[338] A.A. Arkadan et al., Dynamic modeling of high speed aircraft generators during forced power transfer operation, in: 29th Intersociety Energy Conversion Engineering Conference, Monterey, IEEE, 1994, pp. 1-6.

[339] A.A. Arkadan et al., Dynamic modeling of high-speed aircraft generators during forced power transfer operation, J. of Propulsion and Power 11 (6) (1995), 1324-1329.

[340] J.K. Burnham, Predicted dynamic buffet loads from limited response measurements: T-45A horizontal tail, in: 36th Structures, Structural Dynamics and Material Conference, New Orleans, AIAA, 1995, pp. 1504-1514.
[341] K. Carney et al., Nonlinear dynamic behavior in the Cassini spacecraft modal survey, in: 15th Int. Modal Analysis Conference, Orlando, IMAC, 1997, pp. 811-817.

[342] C.F. Chang, Dynamic finite element modeling of aircraft landing system, in: 1995 ASME Design Engineering Technical Conferences, DE 84, ASME, 1995, pp. 1217-1227.

[343] E.R. Christensen, Vibration analyses of fluid-structure systems in the space shuttle main engine, in: 35th Structures, Structural Dynamics and Material Conference, AIAA, 1994, pp. 2580-2590.

[344] M. Coleman et al., Test verification of the Cassini spacecraft dynamic model, in: IEEE Aerospace Conference, Snowmass Village, CO, IEEE, 1997, pp. 289-299.

[345] T. Conklin, K. Barker, Understanding the nature of beam vibrations in space through the flexbeam experiment, G-342, in: Guidance and Control 1996, Advances in Astronautical Science, 92, 1996, pp. 409-428.

[346] A.N. Danilin et al., Dynamics of a space vehicle with elastic deploying tether, Computers and Structures 72(1/3) (1999) 141-147.

[347] D.J. Feld, D.J. Fehr, Complex eigenvalue analysis applied to an aircraft brake vibration problem, in: 1995 ASME Design Engineering Technical Conference, DE 84, ASME, 1995, pp. 1135-1142.

[348] K. Fielden, W. Szyszkowski, Effects of the release angle on the dynamics of deployment of a two-link satellite boom, Computer Modeling and Simulation in Engineering 3(4) (1998), 268-274.

[349] K.C. Frederickson, Helicopter crew seat vibration: criteria, design approaches and a Comanche case study, in: 52nd Annual Forum, Am. Helicopter Soc., 1996, pp. 184-196.

[350] T. Ghosh, Improved method of modal synthesis in the analysis of international space station structures, in: 38th Structures, Structural Dynamics and Material Conference, Kissimmee, AIAA, 1997, pp. 138-145.

[351] D.E. Huntington, C.S. Lyrintzis, Dynamics of multiple-row simplified fuselage structures using a finite element-decaying wave method, J. of Sound and Vibration 180(1) (1995), 2946.

[352] M.H. Kargarnovin, M.H. Sayrafi, Vibration analysis of a small supersonic wing under variation of five geometric parameters, in: Structural Dynamics and Vibration, London, PD 64, ASME, 1994, pp. 249-256.

[353] M. Kia et al., Investigation of steady and dynamic stresses in the AH-64 primary exhaust nozzle, in: 50th Annual Forum, Am. Helicopter Soc., Washington, 1994, pp. 623-635.

[354] H.M. Kim et al., Dynamic loads analysis of photovoltaic arrays for the space station, in: 36th Structures, Structural Dynamics and Material Conference, New Orleans, AIAA, 1995, pp. 2445-2453.

[355] H.M. Kim et al., Dynamic loads analysis of photovoltaic arrays for the space station, Computers and Structures 63(1) (1997), 69-77.

[356] S. Kodiyalam et al., Analysis and test correlation of spacecraft structures using dynamic parameter sensitivities, AIAA J. 32(11) (1994), 2286-2292.

[357] S. Kodiyalam et al., Analysis and test correlation of spacecraft structures using dynamic parameter sensitivities, in: 35th Structures, Structural Dynamics and Material Conference, AIAA, 1994, pp. 1475-1487.

[358] Y. Kohsetsu, Simplified method of analysis of structural vibrations of asymmetric rockets, JSME Int. J., Ser C 41(4) (1998), 695-703. 
[359] R.S. Langley, N.S. Bardell, Review of current analysis capabilities applicable to the high frequency vibration prediction of aerospace structures, Aeronautical J. 102(1015) (1998), 287-297.

[360] C.E. Leak, R.J. Pryputniewicz, Quantitative EOH and FEM hybrid study of vibration of avionics, Proceedings of the SPIE 2545(1995) 286-299.

[361] U. Lee, Equivalent dynamic beam-rod models of aircraft wing structures, Aeronautical J. 99(990) (1995), 450-457.

[362] M. Lillico, R. Butler, Finite element and dynamic stiffness methods compared for modal analysis of composite wings, AIAA J. 36(11) (1998) 2148-2151.

[363] R.B. Malla, A. Ghoshal, Thermally induced vibrations of structures in space, Progress in Astronautics and Aeronautics 168(AIAA) (1995) 68-95.

[364] M. Misawa, Natural frequency prediction of deployable satellite antennas in orbit, Transactions of the Japan Society of Mechanical Engineers, Ser C 62(603) (1996), 4198-4204.

[365] F.A. Moslehy, Vibration technique for space shuttle tiles bond assessment- Part I: Modeling, Modal Analysis 11(1/2) (1996), 49-56.

[366] F.A. Moslehy et al., Vibration technique for space shuttle tiles bond assessment- Part II: Experimental results, Modal Analysis 11 (1/2) (1996), 57-62.

[367] S.A. Mueller, F.A. Moslehy, An inverse vibration method applied to bond evaluation of space shuttle tiles, J. of Vibration and Acoustics, ASME 118(3) (1996), 454-462.

[368] C. Niezrecki, H.H. Cudney, Creating and verifying a research-grade simply-supported cylinder with applications to aerospace structures, in: 16th Int. Modal Analysis Conference, Santa Barbara, 1998, pp. 1240-1249.

[369] M.A. Ozbek, Brake-induced vibration, in: 1995 ASME Design Engineering Technical Conference DE 84, ASME, 1995, pp. 1195.

[370] C.C. Park, J.E. Misel, Effects of a non-linear system (free play) on space shuttle body flap modal response, in: 36th Structures, Structural Dynamics and Material Conference, New Orleans, AIAA, 1995, pp. 840-850.

[371] P. Santini, P. Gasbarri, Structural dynamics of composite wings, J. of Reinforced Plastics and Composites 17(4) (1998), 319-360.

[372] A.K. Sareen et al., Helicopter skid gear dynamic drop analysis and test correlation, in: Annul Forum, Am. Helicopter Soc., Washington, 2, 1998, pp. 1267-1274.

[373] L.K. Shen, Sinusoidal analysis of space shuttle main engine structures, Computers and Structures 50(4) (1994), 481-490.

[374] E.C. Smith et al., Formulation and validation of a finite element model for elastomeric lag dampers, in: 51st Annual Forum, Am. Helicopter Soc., 1995, pp. 1101-1116.

[375] C.W. Spencer, S.L. Killian, Structural analysis of large titanium castings in a high-cycle, rotor-induced vibratory load environment, in: 51st Annual Forum, Am. Helicopter Soc., 1995, pp. 1615-1626.

[376] M. Swaminadham, Dynamics of deployable space structures, in: 1996 ASME Int. Mechanical Engineering Congress and Exhibition, Atlanta, ASME, 1996, pp. 1-7.

[377] S. Tizzi, Application of a numerical procedure for the dynamic analysis of plane aeronautical structures, J. of Sound and Vibration 193(5) (1996) 957-983.

[378] S. Tizzi, Numerical procedure for the dynamic analysis of three-dimensional aeronautical structures, J. of Aircraft 34(1) (1997) 120-130.

[379] M.H. Travis, Nonlinear transient analysis of aircraft landing gear brake whirl and squeal, in: 1995 ASME Design En- gineering Technical Conference, DE 84, ASME, 1995, pp. 1209-1216.

[380] T. Uhl et al., Strain modal testing of a helicopter tail boom, in: 16th Int. Modal Analysis Conference, Santa Barbara, 1998, pp. 1271-1277.

[381] O. Wallrapp, D. Sachau, Space flight dynamic simulations using finite element results in multibody system codes, in: 2nd Int. Conference on Computational Structures Technology, Part 1, Athens, 1994, pp. 149-158.

[382] Z.M. Wang, S.K. Tan, Vibration and pressure fluctuation in a flexible hydraulic power system on an aircraft, Computers and Fluids 27(1) (1998), 1-9.

[383] T.M. Wasfy, A.K. Noor, Application of fuzzy sets to transient analysis of space structures, Finite Elements in Analysis and Design 29(3/4) (1998), 153-171.

[384] T.M. Wasfy, A.K. Noor, Application of fuzzy sets to transient analysis of space structures, in: 39th Structures, Structural Dynamics and Material Conference and Exhibition, Long Beach, 2, 1998, pp. 1172-1182.

[385] H. Yeo, I. Chopra, Effects of modelling refinements on coupled rotor/fuselage vibration analysis, in: Annual Forum, Am. Helicopter Soc., Washington, 1, 1998, pp. 489-501.

[386] Y. Yuan, Study of the effects of negative friction-speed slope on brake squeal, in: 1995 ASME Design Engineering Technical Conference, DE 84, ASME, 1995, pp. 1153-1162.

[387] S.H. Yun, O.A. Bauchau, Improving modal parameter predictions for jointed airframe panels. Part II: Improved numerical model, J. of the American Helicopter Society 43(2) (1998), 164-171.

[388] W. Zheng, Y. Soucy, Application of a multi-channel laser system on modal testing of satellite antenna reflector, in: 15th Int. Modal Analysis Conference Orlando, IMAC, 1997, pp. 464-469.

\section{Automobiles}

[389] R. Aviles et al., Low frequency vibrations in disc brakes at high car speed. Part I: Experimental approach, Int. J. of Vehicle Design 16 (6) (1995), 542-555.

[390] R. Aviles et al., Low frequency vibrations in disc brakes at high car speed- Part II: Mathematical model and simulation, Int. J. of Vehicle Design 16(6) (1995), 556-569.

[391] K.J. Bathe et al., Advances in nonlinear finite element analysis of automobiles, Computers and Structures 64(5/6) (1997), 881-891.

[392] M. Carfagni et al., Methods for shrinking finite element models of carbodies in white, in: 15th Int. Modal Analysis Conference, Orlando, IMAC, 1997, pp. 450-456.

[393] R.N. Coppolino, V.J. Borowski, Integrated modal testing and analysis of a body-on-frame automobile, in: 15th Int. Modal Analysis Conference, Orlando, IMAC, 1997, pp. 400-406.

[394] P. Couderc et al., Vehicle driveline dynamic behaviour: experimentation and simulation, J. of Sound and Vibration 218(1) (1998), 133-157.

[395] T. Ichikawa, I. Hagiwara, Frequency response analysis of large-scale damped structures using componentmode synthesis, Transactions of the Japan Society of Mechanical Engineers, Ser C 39(3) (1996), 450-455.

[396] M. Ishihama et al., Vehicle vibration reduction by transfer function phase control on hydraulic engine mounts, JSME Int. J., Ser C 37(3) (1994), 536-541.

[397] Y. Kamada, H. Seino, Application of finite element model updating technique using experimental data to dynamic analysis 
of suspension in a passenger car, Transactions of the Japan Society of Mechanical Engineers, Ser C 61(588) (1995), 3196-3202.

[398] I. Kuti, Computational procedure for non-linear dynamic analysis of vehicles, Vehicle System Dynamics 30(1) (1998), 37-54.

[399] S.F. Ling et al., Vibration isolation of exhaust pipe under vehicle chassis, Int. J. of Vehicle Design 15(1/2) (1994), 131142.

[400] Y.M. Moon et al., Development of an automotive joint model using an analytically based formulation, J. of Sound and Vibration 220(4) (1999), 625-640.

[401] C.W. Mousseau et al., Vehicle dynamics simulations with coupled multibody and finite element models, Finite Elements in Analysis and Design 31 (4) (1999), 295-315.

[402] M. O'Grady et al., Vibration in an automobile internal rearview mirror, Key Engineering Materials 118-119(1996), 3542.

[403] J. Piranda et al., Improvement of dynamic models in car industry, in: 15th Int. Modal Analysis Conference, Orlando, IMAC, 1997, pp. 85-91.

[404] N. Saga et al., Vibration analysis for alternator stator of automobile by finite element method, Transactions of the Institute of Electrical Engineering Japan D 116(2) (1996), 152-157.

[405] S. Su et al., Total vehicle vibration isolation (TVVI) for automotive and other applications, SAE Special Publication 1363(1998) 17-24.

[406] P.T. Vreede et al., Finite element analysis of tubular energy absorber in automobiles, in: NUMIFORM 95, S. F. Shen and P. Dawson, eds., Balkema, 1995, pp. 893-897.

[407] W. Weber et al., Vibration measurements on a car transmission housing, Proceedings of the SPIE 2358(1994), 365-376.

[408] Y. Zhang et al., Vehicle chassis/suspension dynamics analysis- finite element model vs rigid body model, $S A E$ Special Publication 1338 (1998), 113-126.

[409] H. Zhu, Finite element modal analysis of the engine front end accessory drive systems, Proceedings of the Institution of Mechanical Engineers D 208(1) (1994), 49-54.

\section{Ships}

[410] R.S. Dow, Experimental and theoretical response prediction of steel-stiffened glass-reinforced plastic ship deckhouse subject to blast loading, Marine Structures 7(2/5) (1994), 399416.

[411] J. Kolenda, Simplified description of propeller-induced and kinematically excited shafting transversal vibrations, Marine Technology Transactions 6(1995) 197-218.

[412] C.C. Liang et al., Study of the nonlinear responses of a submersible pressure hull, Int. J. of Pressure Vessels and Piping 75(2) (1998), 131-149.

[413] F. Louarn et al., Dynamic behaviour of a fast sailing monohull in waves, in: 7th Int. Offshore and Polar Engineering Conference, Honolulu, 4, 1997, pp. 712-720.

[414] H. Nobukawa, G. Zhou, Dynamic response analysis of cargo ship in waves, in: 8th Int. Offshore and Polar Engineering Conference, Montreal, 3, 1998, pp. 465-470.

[415] D.L. Prabhakara, P.K. Datta, Static and dynamic elastic behaviour of damaged plates subjected to local inplane loads, Marine Structures 9 (8) (1996), 811-818.

[416] W. Prochnicki, Z. Puhaczewski, Mathematical model of the ship propulsion system for simulation of dynamical processes, Marine Technology Transactions 7(1996), 209-229.
[417] J. Ramos, C.G. Soares, Vibratory response of ship hulls to wave impact, Int. Shipbuilding Progress 45(441) (1998), 7187.

[418] Y. Zheng, L. Yu, New finite element for static and vibrational analysis of double-hull structures, J. Dalian University of Technology, 38(4) (1998), 419-425.

\section{Railways and trains}

[419] E. Adachi, T. Itoh, Theoretical analysis of elastic vibration of railway passenger car body, Transactions of the Japan Society of Mechanical Engineers, Ser C 62(597) (1996), 1685-1690.

[420] R.A. Carman, A.R. Crockett, Finite element vibration analysis of subway structures, in: 1996 National Conference on Noise Control Engineering, Bellevue, 1996, pp. 899-904.

[421] W.J. Chen, Torsional vibrations of synchronous motor driven trains using p-method, J. of Vibration and Acoustics, ASME 117(1) (1995), 152-160.

[422] L. Gavric, Calculation of vibration propagation in a free rail, J. of Physics 4(5) (1994), 73-76.

[423] L. Gavric, Computation of propagative waves in free rail using a finite element technique, J. of Sound and Vibration 185(3) (1995), 531-543.

[424] L. Gry, Dynamic modelling of railway track based on wave propagation, J. of Sound and Vibration 195(3) (1996), 477505.

[425] L. Gry, C. Gontier, Dynamic modelling of railway track: a periodic model based on a generalized beam formulation, $J$. of Sound and Vibration 199(4) (1997), 531-558.

[426] K. Knothe et al., Rail vibrations in the high frequency range, J. of Sound and Vibration 169(1) (1994), 111-123.

[427] M. Moravcik, Response of railway track on nonlinear discrete supports, Vehicle System Dynamics 24(1995), 280-293.

[428] H.A. Nageim et al., Response of a new lightweight rail track system (LR55) to various loading environment, in: ASME Asia Congress and Exhibition, Singapore, ASME, 1997, pp. AA-94.

[429] B. Ripke, K. Knothe, Simulation of high frequency vehicletrack interactions, Vehicle System Dynamics 24(1995), 7285.

[430] P. Shen, J.W. Xing, Calculation of a railway passenger car body using macroelement methods, in: 16th Int. Modal Analysis Conference, Santa Barbara, 1998, pp. 1479-1485.

[431] M. Tanabe et al., Modal transformation method for dynamic interaction analysis of high-speed train, rail and bridge, in: 3rd World Congress on Computational Mechanics, Chiba, Japan, 1994, pp. A4-4.

[432] M. Tanabe et al., Efficient numerical method for dynamic interaction analysis of high-speed Shinkansen vehicles, rail, and bridge, in: ASME Int. Computers in Engineering Conference and Exhibition, ASME, 1994, pp. 567-572.

[433] H. Wakui et al., Study on dynamic interaction analysis for railway vehicles and structures- mechanical model and practical analysis method, Quarterly Report of the RTRI 35(2) (1994), 96-104.

[434] H. Wakui et al., Dynamic interaction analysis for railway vehicles and structures, Proceedings of Japan Society of Civil Engineers 513(31) (1995), 129-138.

[435] T.X. Wu, D.J. Thompson, A double Timoshenko beam model for vertical vibration analysis of railway track at high frequencies, J. of Sound and Vibration 224(2) (1999), 329-348. 
[436] Y.B. Yang, H.H. Hung, A parametric study of wave barriers for reduction of train-induced vibrations, Int. J. for Numerical Methods in Engineering 40(20) (1997), 3729-3747.

\section{Other structures}

[437] J.A.F. Borges et al., About the dynamics of a truck-trailer vehicle, in: 16th Int. Modal Analysis Conference, Santa Barbara, 1998, pp. 1220-1226.

[438] M. Campanelli et al., Chain vibration and dynamic stress in 3D multibody tracked vehicles, Multibody System Dynamics 2(3) (1998), 277-316

[439] M.L. Chargin et al., Nonlinear dynamics of brake squeal, Finite Elements in Analysis and Design 28(1) (1997), 69-82.

[440] P. Couderc et al., Vehicle driveline dynamic behaviour: experimentation and simulation, J. of Sound and Vibration 218(1) (1998), 133-157.

[441] G. Curti, F. Cura, Dynamic behaviour of an SMC bumper for industrial truck, Key Engineering Materials 144(1998), $163-178$

[442] I. Darnell, G.M. Hulbert, An efficient three-dimensional tire model for vehicle dynamics simulations, Mechanics of Structures and Machines 25 (1) (1997), 1-19.

[443] A.J. Day, S.Y. Kim, Noise and vibration analysis of an S-cam drum brake, Proceedings of the Institution of Mechanical Engineers D 210(1) (1996), 35-43.

[444] C. Ferraresi et al., Dynamic behaviour and optimisation of frames for road and mountain bikes, in: 16th Int. Modal Analysis Conference, Santa Barbara, 1998, pp. 387-393.

[445] R.V. Field et al., Structural dynamics modeling and testing of the Department of Energy tractor trailer combination, in: 15th Int. Modal Analysis Conference, Orlando, IMAC, 1997, pp. 1994-2000.

[446] R.V. Field et al., Analytical and experimental assessment of heavy truck ride, in: 16th Int. Modal Analysis Conference, Santa Barbara, 1998, pp. 965-972.

[447] R.F. Fung, H.H. Chen, Dynamic analysis of the flexible connecting rod of a slider-crank mechanism by finite element method, J. of the Chinese Institute of Engineers 19(3) (1996), 381-391.

[448] A.K. Ghosh, M.R. Kumar, Dynamic analysis of supporting structure of mobile antenna, Computers and Structures 63(3) (1997), 633-637.

[449] A.D. Gupta, Dynamic elasto-plastic response of a generic vehicle floor model to coupled transient loads, in: 1997 ASME Pressure Vessels and Piping Conference PVP 351, ASME, 1997, pp. 81-86.

[450] A.D. Gupta, Evaluation of a fully assembled armored vehicle hull-turret model using computational and experimental modal analyses, Computers and Structures 72(1/3) (1999), 177-183.

[451] E. Homsi et al., Minimization of flow induced vibration on a thermoplastic automotive side-view mirror, in: 56th Annual Technical Conference, ANTEC, Atlanta, 1998, pp. 26282634.

[452] J.C. Hung, R.S. Shih, Effective use of experimental design to study dynamic properties in hydroelastic engine mount, in: 53rd Annual Technical Conference, Boston, 3, 1995, pp. 3335-3340.

[453] I.M. Ibrahim et al., Effect of frame flexibility on the ride vibration of trucks, Computers and Structures 58(4) (1996), 709-713.
[454] A. Kamoulakos, B.G. Kao, Transient dynamics of a tire rolling over small obstacles- a finite element approach with PAM-SHOCK, Tire Science and Technology 26(2) (1998), 84-108.

[455] Y. Kang et al., Modal analyses and experiments for engine crankshafts, J. of Sound and Vibration 214(3) (1998), 413430.

[456] B.G. Kao, M. Muthukrishnan, Tire transient analysis with an explicit finite element program, Tire Science and Technology 25(4) (1997), 230-244.

[457] G. Knoll et al., Full dynamic analysis of crankshaft and engine block with special respect to elastohydrodynamic bearing coupling, in: ICE Advanced Engine Design Proceedings, Ft Collins, ASME, 1997, pp. 1-8.

[458] K. Kobayashi et al., Dynamic behavior of continuous bulk handling equipment (3rd Rep, Dynamic behavior analysis of unloaded structure), Transactions of the Japan Society of Mechanical Engineers, Ser C 63(614) (1997), 3688-3695.

[459] T. Kurtay, U. Kocabicak, Prediction of tractor protective cabs using finite element method, in: Structural Dynamics and Vibration, London, PD 64, ASME, 1994, pp. 27-32.

[460] P. Li, M. Hua, Dynamic response of single-shaft radar antenna mechanical system, J. of Vibration Engineering 11(1) (1998), 102-105.

[461] M. Linjama, T. Virvalo, Low-order dynamic model for flexible hydraulic cranes, Proceedings of the Institution of Mechanical Engineers I 213 (1) (1999), 11-22.

[462] I.V. Maslov et al., Finite element analysis of dynamic rigidity of diesel engine housing, in: 1995 ASME Design Engineering Technical Conference, DE 83, ASME, 1995, pp. 189-195.

[463] T. Morita, H. Okamura, Simple modeling and analysis for crankshaft three-dimensional vibrations Part 2: Application to an operating engine crankshaft, J. of Vibration and Acoustics, ASME 117(1) (1995), 80-86.

[464] T. Nakada et al., Excitation mechanism for engine vibration of half-order components, JSAE Review 17(4) (1996), 387393.

[465] E. Negrus et al., Finite element analysis and experimental analysis of natural frequencies and mode shapes for a nonrotating tyre, Vehicle System Dynamics 27S(1997), 221-224.

[466] E.M. Negrus et al., Tire radial vibrations at high speed of rolling, SAE Special Publication 1338(1998), 75-81.

[467] H. Okamura et al., Simple modeling and analysis for crankshaft three-dimensional vibrations, Part 1: Background and application to free vibrations, J. of Vibration and Acoustics, ASME 117(1) (1995), 70- 79.

[468] M.A. Ozbek, Brake-induced vibration, in: 1995 ASME Design Engineering Technical Conference, DE 84, ASME, 1995, pp. 1195.

[469] J. Piranda et al., Determination of equivalent beam properties for hollow girders typically used in the automotive industry, in: 16th Int. Modal Analysis Conference, Santa Barbara, 1998, pp. 1227-1232.

[470] K.W. Poh et al., Steel membrane floors for bodies of large rear-dump mining trucks, Finite Elements in Analysis and Design 32(3) (1999), 141-161.

[471] V. Prakash et al., FEM based approach to crankshaft dynamics and life estimation, SAE Special Publication 1317(1998), 19-31.

[472] M.K. Sarwar et al., Design methodology for tracked vehicles using experimentally identified modal parameters and the finite element method, in: ASME Design Technical Conference, Minneapolis, DE 69/2, ASME, 1994, pp. 491-502. 
[473] M.K. Sarwar et al., Chain link deformation in the nonlinear dynamics of tracked vehicles, J. of Vibration and Control 1(2) (1995), 201-224

[474] J.Y. Shen, W.M. McGinley, Dynamic analysis of a high speed transport model by using a piecewise continuous Timoshenko beam model, in: 4th Int. Conference on Engineering, Construction and Operation in Space, Albuquerque, ASCE, 1994, pp. 27-36.

[475] G.D.P. Silva et al., Numerical and experimental modal analysis of a 4-cylinder diesel engine block, in: 4th World Congress on Computational Mechanics, Buenos Aires, 1998, pp. 261.

[476] A.A. Smaili, M.P. Khetawat, Dynamic modeling of automotive engine crankshafts, Mechanism and Machine Theory 29(7) (1994), 995-1006.

[477] N.S. Soeiro et al., Numerical determination and experimental validation of the gearbox modal model, in: 4th World Congress on Computational Mechanics, Buenos Aires, 1998, pp. 263.

[478] C. Sujatha et al., Whole-body vibration exposure in Indian buses, Heavy Vehicle Systems 2(2) (1995), 160-173.

[479] S. Wojciech, Dynamic analysis of a manipulator mounted on a car chassis, Machine Vibration 5(3) (1996), 142-153.

[480] S.R. Wu, J. Cheng, Advanced development of explicit FEA in automotive applications, Computer Methods in Applied Mechanics and Engineering 149(1/4) (1997), 189-199.

[481] K. Yoon et al., Nonlinear dynamic coefficients of an engine camshaft bearing, in: Structural Dynamics and Vibration, London, PD 64, ASME, 1994, pp. 203-210.

[482] H. Zhu, Finite element modal analysis of the engine front end accessory drive systems, Proceedings of the Institution of Mechanical Engineers D 208(1) (1994), 49-54.

\section{Containment structures}

\section{Reactors and pressure vessels}

[483] E. Altstadt, F.P. Weiss, Finite element based vibration analysis of WWER-440 type reactors, Annals of Nuclear Energy 26(12) (1999), 1037-1052.

[484] D.D. Derksen et al., Modeling the vibration of fuel channels and adjuster units in CANDU reactors to support in-core flux detector noise analysis, in: 4th Int. Conference of CANDU Maintenance, Toronto, 1997, pp. 119.

[485] N.I. Drobyshevski et al., Simulation of the strained condition of the protective cover of the nuclear power station with the PWR-1000 reactor under dynamic load, Applied Energy 33(3) (1995), 118-123.

[486] F.L. Eisinger, Unusual acoustic vibration of a shell and tube process heat exchanger, J. of Pressure Vessel Technology, ASME 116(2) (1994), 141-149.

[487] A.K. Escoe, Flow-induced vibration failure in a steam condenser and its successful redesign, in: ASME Int. Mechanical Engineering Congress and Expo., AD 53-2,ASME, 1997, pp. 239-248.

[488] D. Hilding et al., Calculation of cross-flow-induced fluidelastic vibration of fuel rods in pressurized water reactors, in: 1996 ASME Pressure Vessels and Piping Conference, PVP 328, ASME, 1996, pp. 25-37.

[489] T. Jordan, A computational procedure for coupled electromagnetic-structural dynamic problems and its appli- cation to a fusion reactor blanket, in: Fusion Technology 1994, Elsevier, Amsterdam, 1995, pp. 1181-1184.

[490] H. Kang et al., Theoretical modal analysis of a thick cylinder, Transactions of the Japan Society of Mechanical Engineers, Ser C 60 (575) (1994), 2233-2240.

[491] S. Nakajima, H. Sugino, Response of BWR's steel containment vessel under dynamic internal pressure loading, in: $3 r d$ World Congress on Computational Mechanics, Chiba, Japan, 1994, pp. J5-3.

[492] C.J. Oswald et al., Dynamic design and proof testing of blast containment vessel, in: 1994 Pressure Vessels and Piping Conference, PVP 272, ASME, 1994, pp. 195-211.

[493] S.J. Serhan, Dynamics of nuclear power plant structures with foundation interaction, in: Proceedings of Structural Congress '94, Atlanta, ASCE, 1994, pp. 55-60.

[494] S.E. Sidener et al., Dynamic finite element modeling of the effects of size on the upper shelf energy of pressure vessel steels, J. of Nuclear Materials 239(1/3) (1996), 210-218.

[495] S. Tado et al., Dynamic analysis of the Tokamak support system in ITER, Fusion Engineering and Design 41(Pt B) (1998), 421-429.

[496] H. Yuan, H. Andoh, Two simple methods for estimating frequency of head of reactor with agitatory, in: ASME/JSME Joint Pressure Vessels and Piping Conference, PVP 376, ASME, 1998, pp. 17-26.

\section{Pipes}

[497] A. Arabyan, Y. Jiang, Consistent dynamic finite element formulation for a pipe using Euler parameters, Shock and Vibration 5(2) (1998), 111-117.

[498] B. Cheng, J.S. Chung, Application of thrusts to elastic joints on long vertical pipe in 3-D nonlinear motions- Part II: Numerical examples by MSE and FEM results, in: 8th Int. Offshore and Polar Engineering Conference, Montreal (V 2), 1998, pp. 189-198.

[499] J.S. Chung et al., 3-D coupled responses of deep-ocean crust mining pipe systems to axial bottom vibration and ship motion, in: 4th Int. Offshore and Polar Engineering Conference, ISOPE, 1994, pp. 275-285.

[500] J.S. Chung et al., Three-dimensional coupled responses of a vertical deep-ocean pipe: Part II Excitation at pipe top and external torsion, Int. J. of Offshore and Polar Engineering 4(4) (1994), 331-339.

[501] J.S. Chung et al., Three-dimensional coupled responses of a vertical deep-ocean pipe: Part I Excitation at pipe ends and external torsion, Int. J. of Offshore and Polar Engineering 4(4) (1994), 320-330.

[502] J.S. Gau et al., Dynamic behavior of elastic-plastic simply supported pipes, J. of Pressure Vessel Technology, ASME 116(3) (1994), 306-311.

[503] D. Huang et al., Natural frequencies and mode shapes of curved pipes, Computers and Structures 63(3) (1997), 465473.

[504] H. Kobayashi, T. Fujiwaka, Analytical study of the response of piping with mechanical ratcheting under dynamic loads, in: 1997 ASME Pressure Vessels and Piping Conference, PVP 345, ASME, 1997, pp. 223-228.

[505] G.H. Koo, Y.S. Park, Vibration analysis of a 3D piping system conveying fluid by wave approach, Int. J. of Pressure Vessels and Piping 67 (3) (1996), 249-256.

[506] N.O. Kristiansen et al., Structural modelling of multi-span pipe configurations subjected to vortex induced vibrations, 
in: 8th Int. Offshore and Polar Engineering Conference, Montreal, 2, 1998, pp. 127-133.

[507] K. Kussmaul et al., Structural dynamics and fracture mechanics calculations of the behaviour of a DN 425 test piping system subjected to transient loading by water hammer, Nuclear Engineering and Design 151(2/3) (1994), 473-487.

[508] M. Langthjem, Finite element analysis and optimization of a fluid-conveying pipe, Mechanics of Structures and Machines 23(3) (1995), 343-376.

[509] Y.H. Lin, Y.K. Tsai, Nonlinear vibrations of Timoshenko pipes conveying fluid, Int. J. of Solids and Structures 34(23) (1997), 2945-2956.

[510] K. Matsumoto et al., Study on vibration analysis for laminated composite pipings, Transactions of the Japan Society of Mechanical Engineers, Ser C 61(591) (1995), 4148-4152.

[511] W.A. Moussa, A.N. Abdel Hamid, On the evaluation of dynamic stresses in pipelines using limited vibration measurements and FEA in the frequency domain, in: 1998 Int. Pipeline Conference, Calgary, 2, ASME, 1998, pp. 705-710.

[512] W.A. Moussa, A.N. Abdel Hamid, On the evaluation of dynamics stresses in pipelines using limited vibration measurements and FEA in the time domain, in: ASME/JSME Joint Pressure Vessels and Piping Conference, PVP 368, ASME, 1998, pp. 29-34.

[513] W.A. Moussa, A.N. Abdel Hamid, On the evaluation of dynamic stresses in pipelines using limited vibration measurements and FEA in the time domain, J. of Pressure Vessel Technology, ASME 121(1) (1999), 37-41.

[514] N.M. Price et al., Vibrations of cylindrical pipes and open shells, J. of Sound and Vibration 218(3) (1998), 361-387.

[515] S.R. Reid, J.L. Yang, Non-linear dynamic analysis of cantilever whipping pipes, Proceedings of the Institute of Mechanical Engineers E 212 (3) (1998), 133-149.

[516] N. Sadaoka et al., Development of analysis system for flowinduced vibrations in piping systems, in: ASME/JSME Joint Pressure Vessels and Piping Conference, PVP 363, ASME, 1998, pp. 135-142.

[517] K. Sanada, A. Kitagawa, Finite element model of pipeline dynamics using an optimized interlacing grid system, Transactions of the Japan Society of Mechanical Engineers, Ser C 60(578) (1994), 3314-3321.

[518] K. Sanada, A. Kitagawa, Finite element model of pipeline dynamics, in: Proceedings of the SICE Annual Conference, 1994, pp. 837-842.

[519] T. Sawanobori et al., Vibration analysis of compressor-piping coupled system in air conditioning unit, in: Current Topics in Computational Mechanics, PVP 305, ASME, 1995, pp. $305-326$

[520] Y. Zhao, Random Vibration and ratcheting analysis based evaluation of current ASME code nuclear piping design criteria, in: 1997 ASME Pressure Vessels and Piping Conference, PVP 345, ASME, 1997, pp. 19-26.

[521] Y. Zhao et al., Parametric nonlinear finite element analysis of strain ratcheting in pressurized elbows based on random vibration, Shock and Vibration 3(5) (1996), 373-387.

\section{Storage tanks and other structures}

[522] T.E. Anvick et al., Dynamic behavior of cylindrical water tanks superimposed with a three-way lattice skeleton, in: 13th Structures Congress, Boston, ASCE, 1995, pp. 60-63.

[523] J.M. Brett et al., Dynamic response of an open water-filled tank subjected to an internal explosion, in: 1997 ASME Pressure Vessels and Piping Conference, PVP 351, ASME, 1997, pp. 35-44.

[524] F.J. Buggy et al., Performance of oil storage tanks on vibroflotation improved hydraulic fill in the port of Tampa, Florida, Geotechnical Special Publ., ASCE, 1(40) (1994), 548-560.

[525] A. Dogangun et al., Static and dynamic analysis of rectangular tanks by using the Lagrangian fluid finite element, Computers and Structures 59(3) (1996), 547-552.

[526] F.G. Flores, L.A. Godoy, Forced vibrations of silos leading to buckling, J. of Sound and Vibration 224(3) (1999), 431-454.

[527] K.H. Jeong, Dynamics of a concentrically or eccentrically submerged circular cylindrical shell in a fluid-filled container, J. of Sound and Vibration 224(4) (1999), 709-732.

[528] H. Kawakami, Vibration analysis of fluid-filled rubberlike membrane structures, in: 38th Structures, Structural Dynamics and Material Conference, Kissimmee, AIAA, 1997, pp. 411-420.

[529] B. Liang, J.X. Tang, Vibration studies of base isolated liquid storage tanks, Computers and Structures 52(5) (1994), 10511059 .

[530] T. Mazuch et al., Natural modes and frequencies of a thin clamped-free steel cylindrical storage tank partially filled with water: FEM and measurement, J. of Sound and Vibration 193(3) (1996), 669-690.

[531] C.T.F. Ross, W.D. Richards, The vibration of ring-reinforced circular cylinders under external water pressure, Proceedings of the Institute of Mechanical Engineers C 212(4) (1998), 299-306.

[532] R. Stuart et al., Dynamic analysis of high-level waste storage tanks, Computers and Structures 56(2/3) (1995), 415-424.

[533] J. Tejchman, Dynamical phenomena in silos during discharge, Archives of Civil Engineering 40(1) (1994), 75-88.

[534] J. Tejchman, Shear zones and dynamic effect during silo emptying- Part 2, Archives of Civil Engineering 43(4) (1997), 383-414.

[535] J. Tejchman, Shear zones and dynamic effects during silo emptying- Part 1, Archives of Civil Engineering 43(4) (1997), 353-382.

[536] D. Tran, J. He, Modal analysis of circular cylindrical tanks containing liquids, in: 16th Int. Modal Analysis Conference, Santa Barbara, 1998, pp. 1636-1642.

[537] T. Tsuta et al., Finite element analysis of coupled solid vibration and fluid acoustic systems and application to vibration and sound transmission of tank, Transactions of the Japan Society of Mechanical Engineers, Ser C 60(574) (1994), 19171923.

[538] S. Yoshida et al., Effect of initial stress on natural frequency of cylindrical oil storage tanks, in: 1997 ASME Pressure Vessels and Piping Conference PVP 349, ASME, 1997, pp. 147154.

[539] S. Yoshida et al., Free vibration finite element analysis of fluid-filled double-decker cylindrical tanks, in: ASME/JSME Joint Pressure Vessels and Piping Conference, PVP 370, ASME, 1998, pp. 157- 161. 

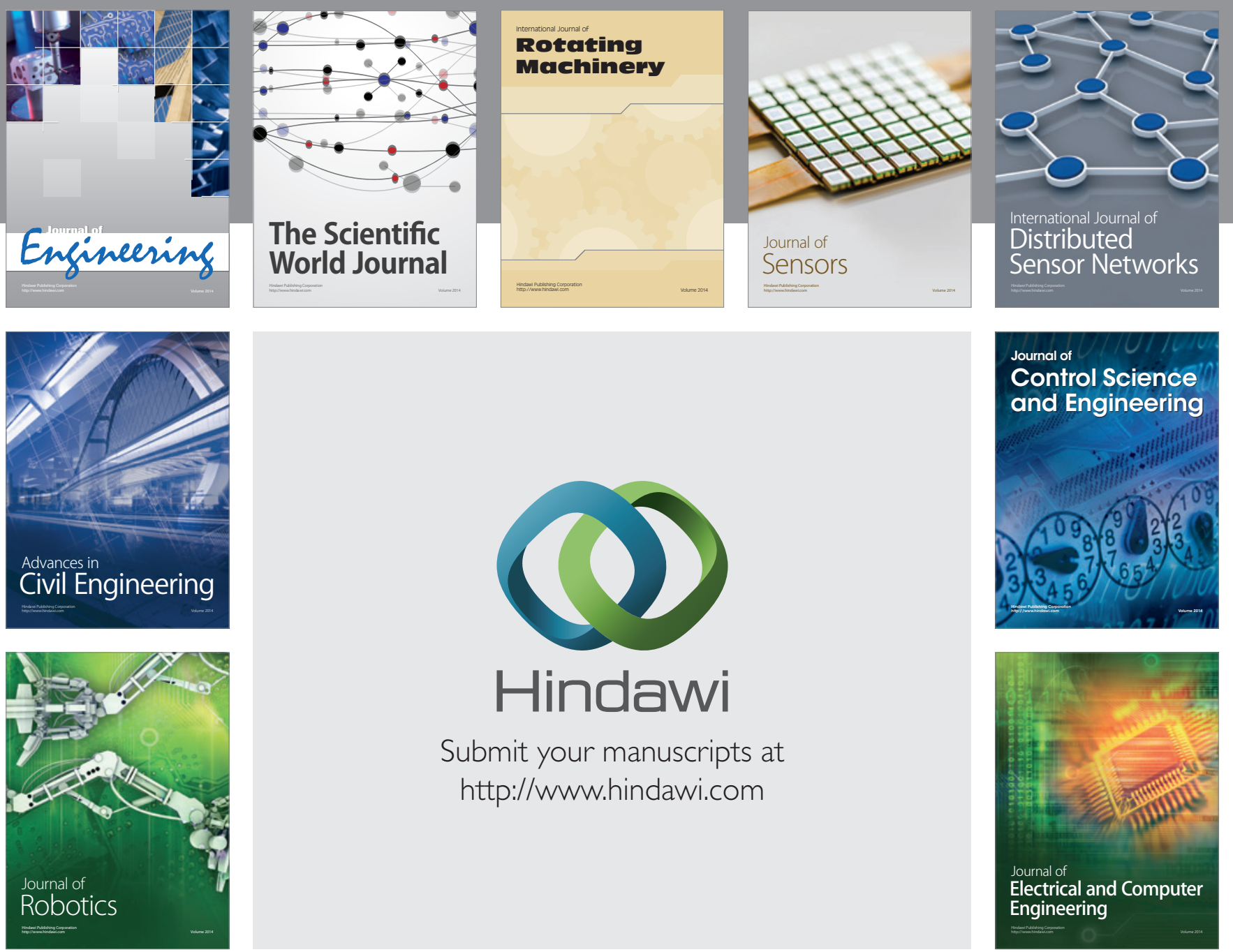

Submit your manuscripts at

http://www.hindawi.com
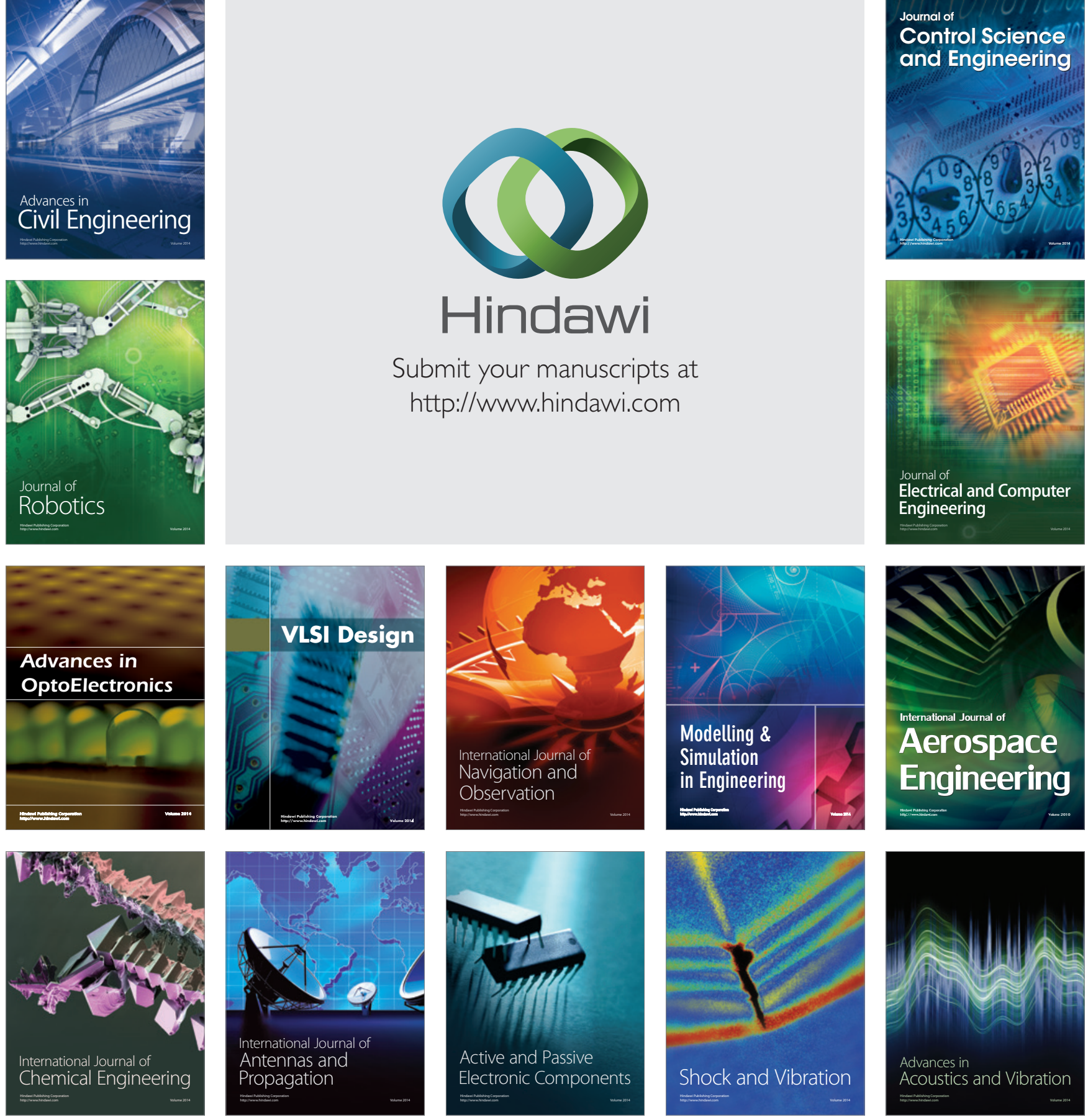